\title{
Evidence of resilience to past climate change in Southwest Asia: early farming communities and the 9.2 and $8.2 \mathrm{ka}$ events
}

Article

Accepted Version

Flohr, P., Fleitmann, D., Matthews, R., Matthews, W. and Black, S. (2016) Evidence of resilience to past climate change in Southwest Asia: early farming communities and the 9.2 and 8.2 ka events. Quaternary Science Reviews, 136. pp. 23-39. ISSN 0277-3791 doi:

https://doi.org/10.1016/j.quascirev.2015.06.022 Available at https://centaur.reading.ac.uk/40539/

It is advisable to refer to the publisher's version if you intend to cite from the work. See Guidance on citing.

To link to this article DOI: http://dx.doi.org/10.1016/j.quascirev.2015.06.022

Publisher: Elsevier

All outputs in CentAUR are protected by Intellectual Property Rights law, including copyright law. Copyright and IPR is retained by the creators or other copyright holders. Terms and conditions for use of this material are defined in the End User Agreement. 


\section{www.reading.ac.uk/centaur}

\section{CentAUR}

Central Archive at the University of Reading

Reading's research outputs online 


\section{Author's Original Manuscript - Preprint}

This is an Author's Revised Manuscript accepted by Quaternary Science Reviews on 19/06/2015.

Flohr, P., Fleitmann, D., Matthews, R., Matthews, W., Black. S. 2015. Evidence of resilience to past climate change in Southwest Asia: Early farming communities and the 9.2 and 8.2 ka events. Quaternary Science Reviews.

The paper will be available online:

DOI 10.1016/j.quascirev.2015.06.22

\section{Evidence of resilience to past climate change in Southwest Asia: Early farming communities and the 9.2 and 8.2 ka events}

Pascal Flohr ${ }^{1,2, *}$, Dominik Fleitmann ${ }^{1,2}$, Roger Matthews ${ }^{1,2}$, Wendy Matthews ${ }^{1,2}$, Stuart Black $^{1,2}$

${ }^{1}$ University of Reading, Department of Archaeology

${ }^{2}$ University of Reading, Centre for Past Climate Change

*Corresponding author. Address: University of Reading, Department of Archaeology, Whiteknights, P.O. Box 227, Reading, RG6 6AB, United Kingdom. E-mail:

p.flohr@reading.ac.uk. Phone: +44 (0) 1183787981

\section{Abstract}

Climate change is often cited as a major factor in social change. The so-called 8.2 ka event was one of the most pronounced and abrupt Holocene cold and arid events. The $9.2 \mathrm{ka}$ event was similar, albeit of a smaller magnitude. Both events affected the Northern Hemisphere climate and caused cooling and aridification in Southwest Asia. Yet, the impacts of the 8.2 and 9.2 ka events on early farming communities in this region are not well understood. Current hypotheses for an effect of the 8.2 ka event vary from large-scale site abandonment and migration (including the Neolithisation of Europe) to continuation of occupation and local adaptation, while impacts of the 9.2 ka have not previously been 
systematically studied. In this paper, we present a thorough assessment of available, qualitychecked radiocarbon $\left({ }^{14} \mathrm{C}\right)$ dates for sites from Southwest Asia covering the time interval between 9500 and 7500 cal BP, which we interpret in combination with archaeological evidence. In this way, the synchronicity between changes observed in the archaeological record and the rapid climate events is tested. It is shown that there is no evidence for a simultaneous and widespread collapse, large-scale site abandonment, or migration at the time of the events. However, there are indications for local adaptation. We conclude that early farming communities were resilient to the abrupt, severe climate changes at 9250 and 8200 cal BP.

\section{Key words}

climate and society; Southwest Asia; Neolithic; 8.2 ka event; 9.2 ka event; resilience

\section{Highlights}

- We assess the impacts of the 9.2 and $8.2 \mathrm{ka}$ BP climate events on Southwest Asian farming communities

- We use over 3000 quality-checked ${ }^{14} \mathrm{C}$-dates in combination with archaeological evidence

- No large-scale collapse/decline or migration took place at around 9250 or $8200 \mathrm{cal}$ BP

- There is some evidence for local adaptation, but not at all sites

- Early farming communities in Southwest Asia were resilient to rapid climate change 


\section{Main text}

\section{Introduction}

Climate is frequently cited as a main factor in socio-economic change, migration, and even collapse of past societies (e.g. deMenocal, 2001). This is relevant globally, but especially so in semi-arid regions like Southwest Asia (Kelley et al., 2015), where water is one of the keyresources for cultural activity. In this region, for example the introduction of agriculture has been linked to the cold and arid Younger Dryas and the onset of the more favourable Holocene (Abbo et al., 2010; Bar-Yosef and Belfer-Cohen, 2002; Belfer-Cohen and GoringMorris, 2011). Increased aridity has also been argued to have contributed to the 'collapse' of the Akkadian empire at around $4200 \mathrm{cal} \mathrm{BP}^{\dagger}$ (Weiss et al., 1993) and the end of the Late Bronze Age around 3200 cal BP (Kaniewski et al., 2013). Furthermore, a series of droughts has been claimed to be one of the factors in inciting the ongoing conflict in Syria (Gleick, 2014; Kelley et al., 2015), providing additional evidence that studying past societal adaptations to abrupt climate events can provide important clues on the factors and dynamics leading to societal changes.

One of the most pronounced and abrupt climatic events of the Holocene occurred around 8200 years ago (the '8.2 ka event', Alley et al., 1997). Numerous proxy data as well as climate models indicate colder and more arid conditions throughout the Northern Hemisphere (Alley and Ágústsdóttir, 2005). A similar event, albeit of a smaller magnitude, occurred at around 9250 cal BP (Fleitmann et al., 2008). As in both cases climatic change occurred within less than a decade, such events are expected to have had a large impact on contemporaneous societies. In contradiction to gradual climate change, it would be much harder to adapt to such rapid events.

\footnotetext{
* PPNB: Pre-Pottery Neolithic B period; PPNC: Pre-Pottery Neolithic C period; FPPNB: final PPNB; PN: Pottery Neolithic, equivalent of Late Neolithic; SPP: summed probability plot.

${ }^{+}$All dates in this manuscript are in calibrated BP (calendar years), in which BP refers to Before Present, with the 'present' at 1950. We specifically use "cal BP" and not "BP" to avoid confusion between calibrated (calendar year) dates and uncalibrated ${ }^{14} \mathrm{C}$ dates, which are in the literature often indicated by $\mathrm{BP}$ or bp. Useries dates, for example used in speleothem dating, are calculated from a different 'present' point, but in this paper we present all dates so that they count back from 1950.
} 
The effects of the 8.2 ka event on societies in Southwest Asia are under discussion, and interpretations vary from collapse and abandonment of sites (Staubwasser and Weiss, 2006; Weninger et al., 2006), large-scale migration (Weninger et al., 2006), to continuation of occupation (van der Plicht et al., 2011) (see section 1.1). However, these current interpretations are either based on rather loose correlations, the use of ${ }^{14} \mathrm{C}$-dates without rigorous quality-check, or studies of single sites. Clearly, a more critical approach is needed, and while detailed studies of single sites (e.g. van der Plicht et al., 2011) are a key resource, a holistic interpretation is now required. Moreover, effects of the 9.2 ka event have not yet been systematically assessed. This research therefore aims at assessing the impact of the $9.2 \mathrm{ka}$ and $8.2 \mathrm{ka}$ climate events on societies in Southwest Asia by evaluating dating evidence in combination with archaeological data. As precise dating is key, the focus is on absolute dating evidence. Therefore this research, while building on earlier studies (Weninger et al., 2006, 2014), aims to significantly improve on these by (1) taking into account all Southwest Asian ${ }^{14} \mathrm{C}$-dated sites contemporaneous with the 9.2 and $8.2 \mathrm{ka}$ events, but also including sites from directly preceding and post-dating periods; (2)

rigorously quality-checking ${ }^{14} \mathrm{C}$-dates; and (3) evaluating archaeological evidence (e.g. is there evidence for continuity or change based on stratigraphy, material culture, or environmental remains?). The combination of taking into account dating evidence and archaeological evidence is essential, as neither can give a full answer on its own. This paper is the first to systematically investigate any impacts of the $9.2 \mathrm{ka}$ event on Southwest Asian society, and expands on previous studies by including eastern regions of Southwest Asia, such as Iran.

\subsection{Potential effects of the 9.2 and 8.2 ka events}

Several studies have investigated the cultural effects of the 8.2 ka event. In western Scotland, a decrease in 'activity events' around 8200 cal BP may indicate a significant drop in population (Wicks and Mithen, 2014). In Northeastern Spain, the most arid part of the Ebro Basin was potentially abandoned around this time (Gonzalez-Samperiz et al., 2009). 
Other studies indicate an effect on Late Mesolithic settlement distribution and subsistence on the Iberian Peninsula (Fernandez Lopez de Pablo and Gomez Puche, 2009; Fernandez Lopez de Pablo and Jochim, 2010), social, technological, and settlement changes in various places in Europe (Gehlen and Schön, 2005), and occupation hiatuses at sites in the Danube Iron Gates region (Bonsall et al., 2002).

In Southwest Asia, the 8.2 ka event has been linked to the apparent decrease in numbers of (large) sites after the Pre-Pottery Neolithic B (PPNB) period in the Southern Levant area, including the abandonment of sites like Jericho and the first phase of settlement at 'Ain Ghazal (Berger and Guilaine, 2009; Migowski et al., 2006; Staubwasser and Weiss, 2006; Weiss and Bradley, 2001; Weninger et al., 2009). It has also been postulated that in Northern Mesopotamia 'Hassuna' style villages with rain-fed farming 'collapsed' and that the first occupation of Southern Mesopotamian villages practicing irrigation occurred at this time (Staubwasser and Weiss, 2006). Hiatuses in occupation at sites like Yumuktepe in Southern Turkey and Sabi Abyad in northern Syria and abandonment of sites at Cyprus have also been associated with the 8.2 ka event (Weninger et al., 2006, 2009, 2014).

The spread of the Neolithic into Western Turkey and into Europe has been linked to the 8.2 ka event as well (Weninger et al., 2006, 2009). While it has since been shown that settlements occurred before 8200 cal BP in Western Anatolia, Greece and the Balkans (Brami, 2014; Budja, 2007; Düring, 2013; Weninger et al., 2014), researchers still link the 8.2 ka event to some aspects or some regions of the Neolithisation of Europe (Berger and Guilaine, 2009; Gronenborn, 2009; Özdoğan, 2011; Pross et al., 2009). Budja (2007), for example, argues that the spread of the Neolithic in Southeast Europe was hampered by the deteriorating climate and floods (see also Bonsall et al., 2002). Also the eastward expansion of the Neolithic, into Central and Eastern Iran, and especially in the Southern Zagros province of Fars, may be contemporaneous with the 8.2 ka event (Weeks et al., 2006; Weeks, 2013). 
At archaeological sites where occupation continued throughout the 8.2 ka event, socio-economic changes have been observed. At Çatalhöyük in Central Turkey, the shift of occupation from the east to the west mound along with social and economic changes, such as a looser settlement lay-out, were observed around this time (Biehl, 2012; Weninger et al., 2006; but see Düring, 2013, and below). At Tell Sabi Abyad in Northern Syria, changes in settlement location within the site, architecture, animal husbandry practices, pottery styles, forms and decoration, and the introduction of stamp seals were contemporaneous with the climatic change (Akkermans et al., 2006, 2010; van der Plicht et al., 2011). In the Southern Zagros, cultural changes (the more mobile 'Mushki' during the event, and 'Jari' farming villages after) may also be associated with the 8.2 ka event (Nishiaki, 2010).

In contrast to the 8.2 ka event, the rapid climate change around 9250 cal BP has only infrequently been linked to social change. The end of Early Mesolithic in Belgium was noted to be "perfectly synchronic" with the event (Robinson et al., 2013). In Southwest Asia, Borrell (2007) has noted that a change in chipped stone industries at Akarçay Tepe in Southeast Turkey was contemporaneous with the event. He also notes that at nearby Tell Halula around the same time hunting was replaced by animal husbandry, and changes in settlement organization and size, building plans, and agriculture took place (Borrell, 2007). However, as the dating and stratigraphy of these sites have not yet been fully published, it is difficult to assess the relationship with the climatic event. In addition, Kuijt and Goring-Morris (2002) place the MPPNB-LPPNB shift in the Southern Levant with associated changes, among many other things in settlement locations and lay-out, at $9250 \mathrm{cal}$ BP, although they do not link this to climatic change. However, the majority of authors place this transition earlier, around 9500 cal BP (e.g. Benz, n.d.; Rollefson, 2008). 


\section{Climate evidence}

\section{$2.1 \quad 8.2$ ka event}

The 8.2 ka event is apparent in many records, especially from the Northern Hemisphere (Abrantes et al., 2012; Alley and Ágústsdóttir, 2005; Alley et al., 1997; Wiersma and Renssen, 2006). The event itself was most likely caused by meltwater escaping from Lake Agassiz-Ojibway into the Atlantic Ocean via the Hudson Bay, altering termohaline circulation (Barber et al., 1999; Clarke et al., 2003, 2004; Teller et al., 2002).

The existence of a climate anomaly around $8200 \mathrm{cal}$ BP is clearly visible in ice cores from Greenland (Fig. 1) (Alley et al., 1997; Johnsen et al., 2001; Thomas et al., 2007), where air temperatures dropped by 3 to $6 \pm 2{ }^{\circ} \mathrm{C}$ (Alley et al., 1997; Kobashi et al. 2007; Leuenberger et al., 1999). Sharp decreases in air temperature of up to $4^{\circ} \mathrm{C}$ are also evident in many other high-resolution proxy records from the circum-Atlantic and Mediterranean basin (Alley and Ágústsdóttir, 2005; Klitgaard-Kristensen et al., 1998; Morrill et al., 2013; Pross et al., 2009; Veski et al., 2004; von Grafenstein et al., 1998; Wiersma and Renssen, 2006). While temperatures decreased hemisphere-wide, the effects on precipitation are less clear. It appears that wetness increased north of $42^{\circ}$ latitude, while aridity increased south of this (Abrantes et al., 2012; Berger and Guilaine, 2009). For the Eastern Mediterranean, a reduction in precipitation of around $17 \%$ has been calculated (Pross et al., 2009).

The event is well-dated to have taken place between 8250 and $8000 \mathrm{cal}$ BP and to have lasted around 160 years (van der Plicht et al., 2011). Cheng et al. (2009) give 82108090 cal BP based on various precisely dated speleothem records. Dating based on ice cores gives $8175 \pm 30$ to 8025 cal BP (Kobashi et al., 2007), 8247-8086 cal BP with a central event at 8212-8141 cal BP (Thomas et al., 2007), or, revised most recently, $8250+10 /-40$ to $8090+50 /-10$ cal BP (Rasmussen et al., 2014, maximum counting error 49 years). This is in agreement with tree rings from Germany (8220-7950 BP, Spurk et al., 2002), and lake cores from Norway (8220-8000 cal BP, Hormes et al., 2009). Some research dates the event slightly earlier (ca 8290 cal BP), but this may be due to marine dating uncertainties (Ellison et al., 2006; Klitgaard-Kristensen et al., 1998). 


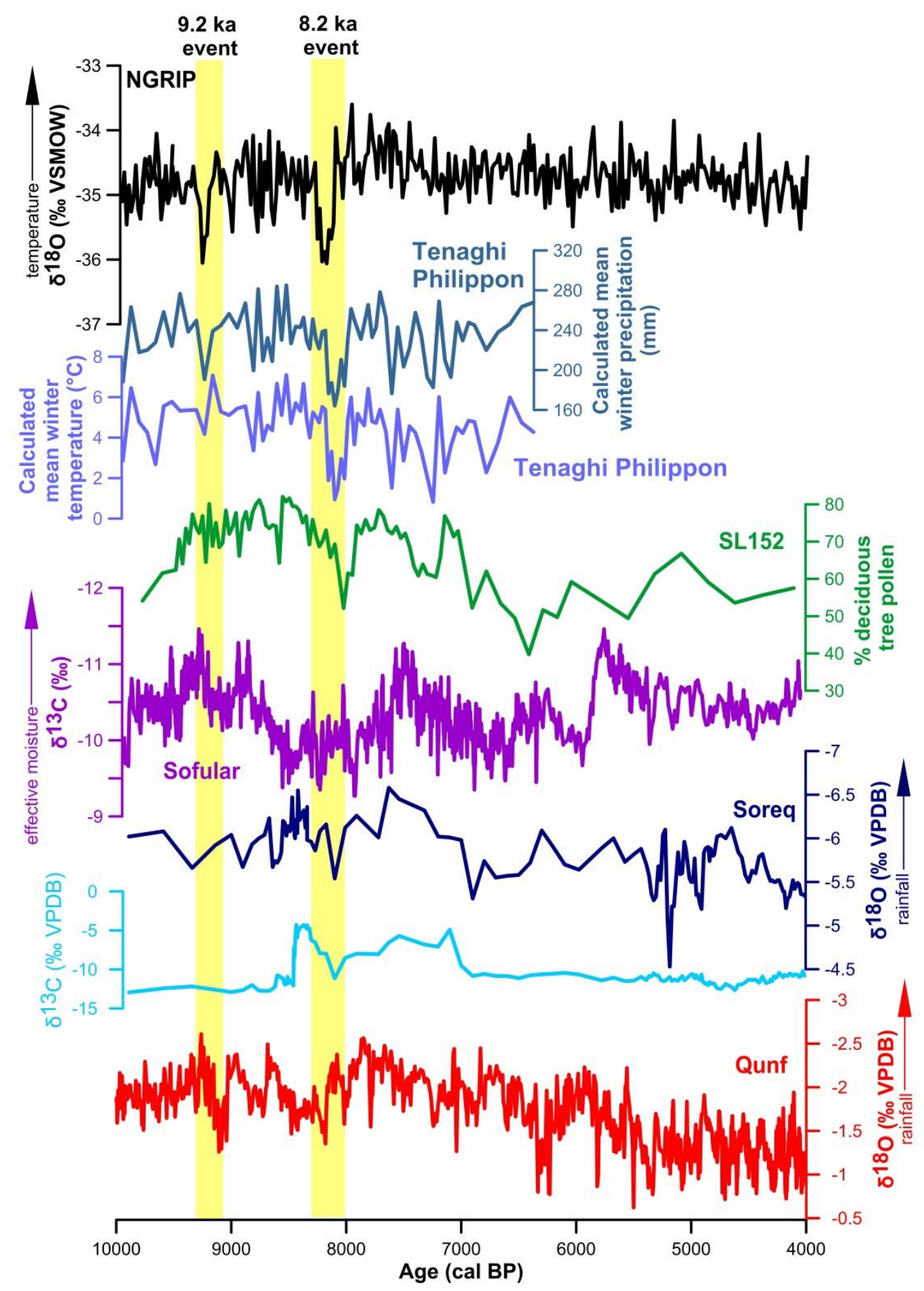

Figure 1 - Selected climate proxies showing the 9.2 and/or 8.2 ka events. Greenland ice core (NGRIP) $\delta^{18} \mathrm{O}$, compared to high-resolution, well-dated proxies from in and nearby Southwest Asia. From top to bottom: NGRIP $\delta^{18} \mathrm{O}$ (Johnsen et al., 2001), precipitation and temperature calculated from percentage pollen from Tenaghi Philippon in Greece (Pross et al., 2009), percentage of deciduous tree pollen in the SL152 marine core from the Aegean Sea (Kothoff et al., 2008), $\delta^{18} \mathrm{O}$ and $\delta^{13} \mathrm{C}$ from Soreq Cave in Israel (Bar-Matthews et al., 1999, 2003), and $\delta^{18} \mathrm{O}$ from Qunf Cave in Oman (Fleitmann et al., 2003). Locations are indicated in Fig. 3. 
High resolution, well-dated records from the Southwest Asia region indicate an impact of the climate event in this region (Fig. 1). Soreq Cave, located in the Southern Levant, shows a slight, $1 \%$, increase in $\delta^{18} \mathrm{O}$ and a reversal of Early Holocene deluge effects with a sharp, 7\%o, decrease in $\delta^{13} \mathrm{C}$ between 8200 and 8000 cal BP (Bar-Matthews et al., 1999, 2003). Sofular speleothem $\delta^{13} \mathrm{C}$ and ${ }^{234} \mathrm{U} /{ }^{238} \mathrm{U}$ increase, while growing rates are low, all indicating a decrease in effective moisture/water availability, albeit over a longer time span, from around 8600 cal BP onwards (Göktürk et al., 2011). In Lake Nar, $\delta^{18} \mathrm{O}$ increased, which was interpreted as increasing aridity, although as a peak of a longer, 800-year, drying trend (Dean, 2014). Dead Sea levels are clearly low around this time (Migowski et al., 2006), but the decline appears to start several hundreds of years earlier already.

In contrast, no clear evidence is available in the Lake Golhisar or Lake Van records (Eastwood et al., 2007). In the latter there is a decline in Poaceae pollen followed by a Pistachio decrease, but at the same time oak pollen\% increases, indicating continued humidity (Wick et al., 2003). There is also no large anomaly in the Jeita Cave record (Verheyden et al., 2008).

Some more information is available from areas directly surrounding Southwest Asia. Speleothem $\delta^{18} \mathrm{O}$ from Qunf Cave in Oman increase at around 8200 cal BP (Fleitmann et al., 2003, 2007). At the same time, deciduous tree pollen decline in and near the Aegean, while steppe pollen increase (Bordon et al., 2009; Dormoy et al., 2009; Kotthoff et al., 2008; Peyron et al., 2011; Pross et al., 2009). Marine records from the Aegean (LC21) and Adriatic (LC25) indicate that the Early Holocene sapropel, indicating humid conditions, was interrupted around 8200 cal BP (Mercone et al., 2000, 2001). This coincided with changes in foraminifera and geochemistry, indicating increased salinity in those cores as well as in core 967 from the Eastern Mediterranean (Emeis et al., 2000; Mercone et al., 2000, 2001). In a core from Marmara, low sea surface temperatures (SST) and a Neogloboquadrina incompta peak occurred also around $8200 \mathrm{cal}$ BP, although before the sapropel interruption (Sperling et al., 2003). In the Red Sea core GeoB 5844-2, UK'37 derived SST reconstruction shows a drop contemporaneous with an increase in G. ruber $\delta^{18} \mathrm{O}$ and $\Delta \delta^{18} \mathrm{O}$ (Arz et al., 2003). 


\section{$2.2 \quad 9.2$ ka event}

Around 9250 cal BP, meltwater also escaped from Lake Agassiz, although on a much smaller scale than a millennium later $\left(1600 \mathrm{~km}^{3}\right.$ compared to $163000 \mathrm{~km}^{3}$ ) (Teller et al., 2002). An anomaly is clearly visible in Greenland ice core $\delta^{18} \mathrm{O}$ (Fig. 1) (Rasmussen et al., 2007). Notwithstanding the relatively low influx of meltwater, the event evidently had an impact on a nearly global climate, as summarized by Fleitmann et al. (2008), who show an anomaly in ten records from various climate zones including Greenland, Alaska, Europe, the Arabian Peninsula, and China. In addition, there is a meltwater spike in Norway lake records (Hormes et al., 2009).

The event was dated to $9210 \pm 80$ cal BP in Oman and China speleothems, and centres on 9250 cal BP based on ice cores and the Bamberg (Germany) tree ring record (Fleitmann et al., 2008 and references therein). The Norway lake record gives a slightly earlier, but still overlapping date of 9390-9145 cal BP (Hormes et al., 2009). Rasmussen et al. $(2007,2014)$ dated the event from $9300+10 /-20$ to $9190+30 /-10$ cal BP in the Greenland ice cores (9350-9240 b2k, estimated maximum counting error of 70 years), with a duration between 40 and over 100 years.

The 9.2 ka event is not very prevalent in most Southwest Asian records, but is clearly present in Qunf Cave (Fig. 1). There is also some evidence for a dry signal around $9200 \mathrm{cal}$ BP in Lake Nar, based on an increase in $\delta^{18} \mathrm{O}$ (Dean, 2014). In core SL21 from the Aegean, S. elongatus peaks that were associated with the arid $8.2 \mathrm{ka}$ event also occurred around 9500 and 9030 cal BP (Marino et al., 2009). Pollen records from the Aegean indicate a (slight) decline in precipitation around 9250 cal BP (Fig. 1, Pross et al., 2009). Because of the short duration of the event, records have to have a very high resolution to pick it up.

\subsection{Actual impact}

In summary, there is clear evidence for rapid climate change events in the northern hemisphere around 9250 cal BP and especially around 8200 cal BP. This evidently impacted vegetation, at least for the $8.2 \mathrm{ka}$ event. In the Aegean region, decreases in deciduous tree 
species and increases in steppe species indicate a temperature decrease of 1 to $4{ }^{\circ} \mathrm{C}$ around 8200 cal BP (Dormoy et al., 2009; Peyron et al., 2011; Pross et al., 2009), probably due to reduction in winter precipitation (Marino et al., 2009), and a precipitation decrease of 17\% (Pross et al., 2009).

In addition, two important issues should be kept in mind. Firstly, the 8.2 ka event was superimposed on a more general aridification/cooling from 8600 to 7800 cal BP (Rohling and Pälike, 2005). This is also visible in several of the Southwest Asian records. For example, the pollen perturbation in the Aegean takes place between 8400 and 8100 cal BP, while the Sofular $\delta^{13} \mathrm{C}$ anomaly already starts around 8600 cal BP (Fig. 1). Recently, some changes, like migration into Western Anatolia, were connected to this longer-term aridification (Weninger et al., 2014). Nonetheless, the current paper focuses on the more rapid $8.2 \mathrm{ka}$ event, as the speed of onset as well as the size of the rapid event would have been most severe, and the event is thus most likely to have impacted societies (see Clare and Weninger, 2010; Meze-Hausken, 2000). Secondly, both the 9.2 ka and 8.2 ka events were superimposed on a wetter Early Holocene period (Robinson et al., 2006). Especially the 9.2 ka event took place in the middle of the Holocene Climatic Optimum.

\section{The potential impacts of the 8.2 and 9.2 ka events on societies}

What kind of societal impact do we expect to see at times of an abrupt and persistent change to colder and drier climatic conditions? Based on archaeological, historical, and modern examples (e.g. Black et al., 2011b; Clare and Weninger, 2010; Halstead and O'Shea, 1989; Leppard, 2014; Meze-Hausken, 2000; Weiss and Bradley, 2001), we identify four main 'responses': (1) Collapse/decline of societies, (2) Long distance migration, (3) Adaptation and (4) No impact.

The 'collapse' of societies (Weiss and Bradley, 2001), or, as in the Neolithic the term collapse is probably not applicable, large-scale decline, includes a sharp increase in siteabandonment (temporary or long-term) because of starvation and migration (Weninger et al., 2009). 
Long-distance migration (Black et al., 2011b; Halstead and O'Shea, 1989; Leppard, 2014; Meze-Hausken, 2000) may be visible by sites being abandoned in certain regions and new sites being established in other regions. Traditionally, material culture was expected to change as a result, but it is now known that this may not be as clear-cut. Elemental and isotope studies may help identify such issues in future.

Adaptation can be functional, such as diversification of subsistence strategies, gathering of wild plants or keeping different animals, intensification or extensification of agriculture, increased short-distance mobility, or searching for non-agricultural income (Block and Webb, 2001; Leslie and McCabe, 2013; Meze-Hausken, 2000). We also include here preventative strategies, like storage and exchange or social networks (Halstead and O'Shea, 1989). In addition, adaptation strategies include practices which may, at least in our view, not be effective, such as intensification of ritual practices (Huffman, 2009; Sillitoe, 1993). Establishing local adaptation practices in archaeology requires well-dated, thoroughly studied archaeological sites spanning the time preceding and directly after the start of the climatic change. In that way, changes in use of plants and animals (including isotope studies to assert mobility), pottery (including, for example, lipids) and skeletal material can indicate changes in subsistence, health, and diet; certain objects and materials can indicate longdistance networks; and changes in for example figurines and treatment of the dead could indicate ritual changes.

However, we emphasize that any categorisation by its nature will be simplistic, and combinations and fluidity between categories is probably always present. In addition the relationship between changing climate and such responses is far from linear and simple as different factors are at play. Furthermore, it should be kept in mind that even if such changes occur at the same time as climatic events, this does not evidence causality (Roberts et al., 2011; van der Plicht et al., 2011). 


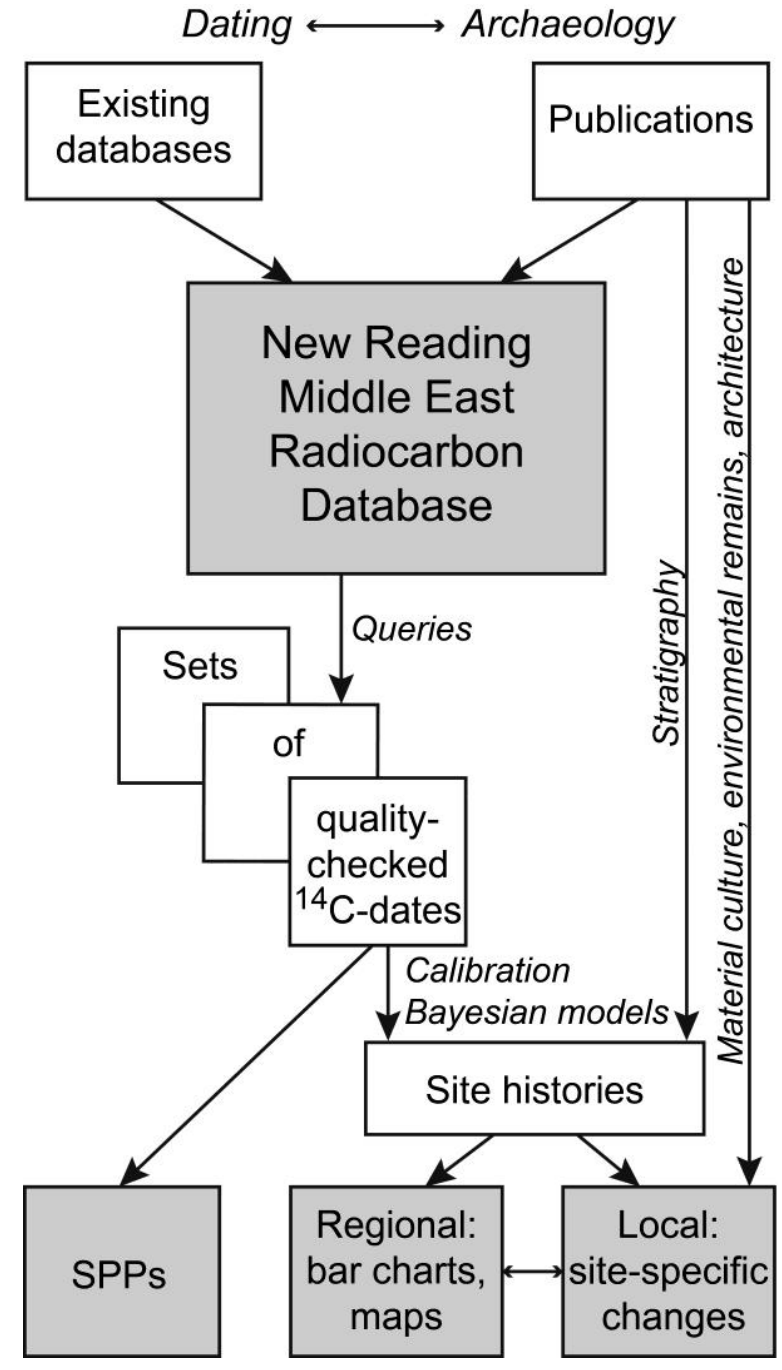

Figure 2 - Schematic overview of used methods.

\section{Materials and Methods}

The approach is shown in a schematic flowchart (Fig. 2). To examine potential cultural impacts of the 9.2 and 8.2 ka events, we compiled quality-checked ${ }^{14} \mathrm{C}$-dates to analyse occupation histories at all $83{ }^{14} \mathrm{C}$-dated (where $\mathrm{n}>2$ ) Neolithic sites between 9500 and 7500 cal BP, shown as bar-charts (Fig. 3) and site distribution maps (Fig. 4). In addition, we present summed probability plots (SPPs) for different regions in Southwest Asia for the period between 10,000 and 6000 cal BP (Fig. 5).

\subsection{Radiocarbon database}

A database of 6778 radiocarbon dates for Southwest Asia was compiled, using dates from existing databases (Benz, n.d.; Böhner and Schyle, 2002-2006; Weninger et al., 2013) and 
checking these against, and adding additional information from, the original publications. In addition, new dates were collected from radiocarbon datasets and archaeological publications. The extensive new database includes 3397 dates for the periods between 11000 to 5000 uncalibrated ${ }^{14} \mathrm{C}$-years from the present-day countries of Turkey, Syria, Lebanon, Israel and the Palestinian territories, the Sinai region of Egypt, Iraq, and Iran (Table S1). The Arabian Peninsula, the Caucasus, and Cyprus were excluded for this paper. The spatial distribution of ${ }^{14} \mathrm{C}$-dated sites is uneven, with a scarcity of dated sites in Iraq and Iran (Fig. 3-4), due to research biases and the political situation.

\subsection{Quality-checking of ${ }^{14} \mathrm{C}$-dates}

Before being used in analyses, the ${ }^{14} \mathrm{C}$-dates were rigorously quality-checked, as unreliable dates can lead to erroneous conclusions. This is one of the major advantages of our research. The following criteria were used for the quality check:

1. Dating precision. Considering that the aim of this research is to compare cultural events to rapid climate events (with their onset occurring in less than a decade), a precise chronology is of utmost importance. Samples with a standard deviation $(1 \sigma)$ larger than 150 or $100{ }^{14} \mathrm{C}$ years were therefore excluded. Age uncertainties of ${ }^{14} \mathrm{C}$ dates are caused by equipment resolution, measurement stability, and the random nature of radioactive decay (Taylor 1987; van der Plicht and Bruins, 2005: 259). Dates with standard deviations above 100 years are more likely to have had a problematic laboratory treatment or concern a problematic sample (e.g. with a low carbon content). Moreover, use of such ${ }^{14} \mathrm{C}$-dates would make events or site occupation seem longer than they were likely in reality. For the SPPs, only dates with a standard deviation of 100 or below were used; for site-specific analyses, dates with standard deviations between 100 and 150 that met all other criteria were taken into account with caution, as in some cases such large errors can be reduced using Bayesian modelling (Bronk Ramsey, 2009a). 
2. Material. Bulk samples were excluded, as the inclusion of sediment or roots may cause contamination (Gillespie, 1984; van der Plicht and Bruins, 2001). ${ }^{14} \mathrm{C}$-dates obtained from shell were also excluded, as it can give erroneous dates due to recrystallization and hard water effects, also in terrestrial species (Bowman, 1990; Olsson, 2009). Other material that is excluded is burnt bone, and most bone apatite and carbonate dates (Mook and Waterbolk, 1985). Bone collagen on the other hand is accepted when analysed after the 1990s (see Olsson, 2009: 14). Unfortunately, many ${ }^{14} \mathrm{C}$-dates had to be rejected because the sample material was not published. Charcoal, charred seeds, and recently analysed bone collagen were preferred and formed the majority of samples used in the analyses. None of these is unproblematic though. Charcoal dates may be too old for their context due to old wood effects (Bowman, 1990; van der Plicht and Bruins, 2001, 2005). On the other hand, seeds are more likely to be transported through sediment layers (Finlayson et al., 2011: 132; van der Plicht and Bruins, 2001, 2005). Therefore, we make a distinction between ${ }^{14} \mathrm{C}$-dates derived from short-lived (seeds, twigs, and reliable bone samples) and potentially long-lived (all other charcoal) samples, but do not exclude either category.

3. Samples reported as problematic by the laboratory were excluded. Where available, $\delta^{13} \mathrm{C}$ and \%C were checked (e.g. for charred $\mathrm{C}_{3}$ plant remains these should be ca $22 \%$ to $-24 \%$ and $>60 \%$, respectively) (van der Plicht and Bruins, 2005).

4. Reliability of the laboratory. Samples from laboratories that did not take part in the laboratory inter-comparison exercises (Scott et al., 2004) were used with caution in site-specific analyses, but included in the SPPs. Samples without laboratory number were rejected.

5. Year of analysis. Analyses conducted before the 1980s were accepted with caution (when meeting the other criteria), but nonetheless included in the SPPs.

6. Context. Only dates clearly connected to an archaeological context were used. 


\subsection{Analyses}

Quality-checked ${ }^{14} \mathrm{C}$-dates were grouped on regional and site-specific scales. The regional compilations were summarized in SPPs with date ranges from 10000 to 6000 cal BP. The dates per site were used to assess when sites were occupied, using Bayesian modelling where possible (limited to sites occupied between 9500 and 7500 cal BP). This information was then used to plot settlement distribution, as well as to assess when intra-site cultural change took place. Each of these analyses is explained in more detail below. All dates were calibrated using the IntCal 13 curve and calibration and model construction were conducted in OxCal version 4.2 (Bronk Ramsey, 2009a, b; Reimer et al., 2013).

\subsubsection{Settlement distribution maps and site occupation bar charts}

Based on the site-by-site assessment of occupation, settlement distribution maps (200 year time slots) were created and bar charts were compiled for each of the 83 sites between 9500 and 7500 cal BP for which at least two quality-checked ${ }^{14} \mathrm{C}$-dates were available. Although the stratigraphical and archaeological context were taken into account, it remains possible that occupation was longer than suggested by the dates, for example because of erosion (Roberts et al., 2007), or because excavations have not yet reached virgin soil. As such, Fig. 3 and 4 indicate when occupation was likely present, but not necessarily when it was absent. Detailed information for each site is available in Table S2.

The settlement distribution is compared to modern precipitation zones in Fig. 4. This was compiled using the KNMI Climate Explorer (van Oldenborgh, 2015), and based on CRU TS3.22 1901-2013 0.5 grid data (Climatic Research Unit, University of East Anglia). Though modern mean annual precipitation is different from that in the Neolithic, precipitation gradients are for a large part affected by topography and as such are expected to be similar (Black et al., 2011a).

4.3.2 Summed probability plots (SPPs) 
SPPs were created in OxCal (using boundaries) to summarize available ${ }^{14} \mathrm{C}$-dates per region. In this way, it is possible to assess when (Neolithic) occupation in a region is likely to have started, assuming that if ${ }^{14} \mathrm{C}$-dated archaeology is present, people were present. Such assertions were subsequently checked against site-specific data. We do not use SPPs as a direct demographic proxy (Shennan et al., 2013; Shennan and Edinborough, 2007; Timpson et al., 2014) as this approach has several problems (Armit et al., 2013; Contreras and Meadows, 2014; Williams, 2012) and the Southwest Asia dataset does not meet the basic requirements to overcome these for several reasons. Firstly, many of the regions only have a small number of ${ }^{14} \mathrm{C}$-dates from a limited number of sites (Table S3). Secondly, there is a heavy research bias towards certain periods, regions, and sites. Though such a bias can partly be overcome by site-phase corrections (Shennan et al., 2013; Shennan and Edinborough, 2007), the remaining number of ${ }^{14} \mathrm{C}$-dates is only very small for the Southwest Asian sample. Nonetheless, such corrections were added for comparative reasons (Fig. 5). They were done by combining dates for the same phases within a site using the R_Combine function in OxCal (Shennan and Edinborough, 2007). Where excavators did not indicate any, or no detailed, phasing (for example only 'Late Neolithic'), dates were separated in artificial 200-year bins.

\subsubsection{Intra-site cultural change}

For sites with a sufficient number of ${ }^{14} \mathrm{C}$-dates and accessible and sufficient stratigraphic information, Bayesian models were constructed in OxCal (Bronk Ramsey, 2009a, b). Due to often limited information provided by publications or limited knowledge of internal stratigraphic relations, these mostly remain coarse, but nonetheless give improved information on when phases of each site can be dated. When additional archaeological information was provided in publications and reports, an assessment was made of whether socio-economic changes occurred contemporaneously with either the 8.2 or 9.2 ka events (sites are specified in section 5.3, see also Fig. S2). 

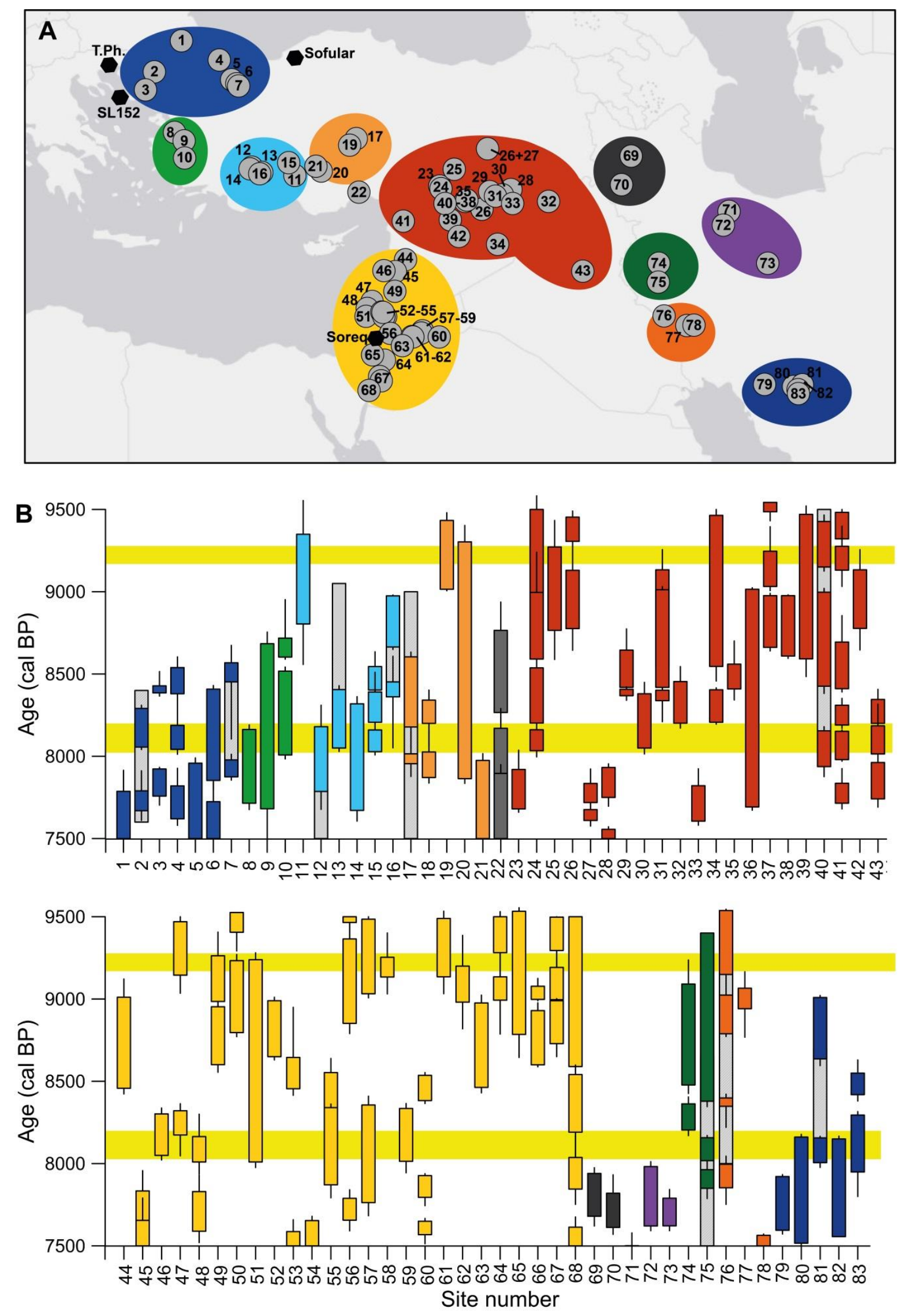

Figure 3 - Map showing locations of all discussed sites and of selected Eastern Mediterranean highresolution climate proxies (basemap from ArcGIS by Esri) and bar charts for all Southwest Asian ${ }^{14} \mathrm{C}$ - 
dated sites with at least two dates between 9500 and 7500 cal BP. The diagrams indicate the range covered by the available ${ }^{14} \mathrm{C}$-dates within $1 \sigma$ (box) and $2 \sigma$ (line). Where possible, the diagrams are based on Bayesian modelling, but where detailed stratigraphic information was lacking, they are based on individual ${ }^{14} \mathrm{C}$-dates (specified in Table S2). Grey bars indicate archaeological information, when different from ${ }^{14} \mathrm{C}$-evidence.

1. Aşağı Pınar; 2. Hoca Çeşme; 3. Uğurlu; 4. Yarımburgaz; 5. Ilıpınar; 6. Menteşe; 7. Barcın Höyük; 8. Ege Gübre; 9. Ulucak; 10. Çukuriçi; 11. Suberde; 12. Kuruçay Höyük; 13. Höyücek; 14. Hacılar; 15. Erbaba; 16. Bademağaci; 17. Tepecik-Çiftlik; 18. Pinarbaşi B; 19. Musular; 20 Çatalhöyük East; 21. Çatalhöyük West; 22. Yumuktepe; 23. Fistikli Höyük; 24. Akarçay Tepe; 25. Gritille; 26. Çayönü; 27. Girikihaciyan; 28. Chagar Bazar; 29. Tell Halaf; 30. Kashkashok; 31. Seker el-Aheimar; 32. Thalathat; 33. Umm Qseir; 34. Bouqras; 35. Damishliyya; 36. Tell Sabi Abyad I; 37. Tell Sabi Abyad II; 38. Tell Sabi Abyad III; 39. Abu Hureyra; 40. Tell Halula; 41. El-Kerkh sites; 42. Qdeir I; 43. Tell es-Sawwan I; 44. Tell Nebi Mend; 45. Ard Tlaili; 46. Byblos; 47. Betzet 1; 48. Kfar Samir; 49. Ramad; 50. Tell Rakan; 51. Atlit-Yam; 52. Tel 'Ali; 53. Tabaqat al-Buma; 54. AlBasatin; 55. Sha'ar Hagolan; 56. 'Ain Ghazal; 57. Dhuweila; 58. Burqu' 35; 59. Burqu' 27; 60. Wisad Pools; 61. Azraq 31; 62. Bawwab al-Ghazal; 63. Jilat 13; 64. Khirbet Hammam; 65. Nahal Hemar; 66. Ba'ja; 67. Basta; 68. Issaron; 70. Hajji Firuz; 71. Tepe Ebrahim Abad; 72. Chahar Boneh; 73 Tepe Sialk; 74. Sarab; 75. Tepe Guran; 76. Ali Kosh; 77. Chogha Bonut; 78. Chogha Mish; 79. Tol-e Nurabad; 80. Tol-e Bashi; 81. Rahmatabad; 82. Tale Jari B; 83. Mushki.

\section{Results \& Discussion}

\subsection{Did early farming societies collapse or decline at the time of the 9.2 or $8.2 \mathrm{ka}$} events?

Fig. 3 and 4 show that there is no clear evidence for a widespread or regional abandonment at around $9250 \mathrm{cal}$ BP or $8200 \mathrm{cal} \mathrm{BP}$, or at any other point in time between 9500 and 7500 cal BP. There is no convincing ${ }^{14} \mathrm{C}$-evidence for any site being abandoned at around 9250 cal BP. The only two sites where ${ }^{14} \mathrm{C}$-dates are absent within 100 years from the $9.2 \mathrm{ka}$ event, Betzet 1 (Fig. 3 site 47) and Azraq 31 (site 61), only have two dates for the period. Of 83 sites, only four sites lack ${ }^{14} \mathrm{C}$-dates between 8200 and 8100 cal BP and may have been abandoned, while many others appear to have remained occupied (Fig. 3, Fig. S1). Six sites show a short-term lack of ${ }^{14} \mathrm{C}$-dates around 8200 cal BP in their $1 \sigma$ range and may have 
been temporarily abandoned; however, this is not the case in their $2 \sigma$ range and archaeological evidence frequently indicates continuity (see Fig. S1 and section 5.3).

Sites that were potentially abandoned around 9250 or 8200 cal BP were not specifically located in marginal areas with generally drier or colder climatic conditions, as would be expected (Fig. 4, Fig. S1). It is possible that Sarab (Fig. 3 site 74) was abandoned because of colder conditions, as it is situated high in the Zagros mountains (ca $1400 \mathrm{~m}$ asl). Similarly, it is possible that Bouqras (Fig. 3 site 34), close to the Euphrates River but in a very low rainfall zone ( $<200 \mathrm{~mm}$ of annual rainfall), was abandoned because of increased aridification (nonetheless, the evidence is ambiguous, as the ${ }^{14} \mathrm{C}$-dates indicate that the site was probably abandoned already around 8300 cal BP and its main, PPNB, occupation had already been abandoned centuries before, while its 'Proto-Hassuna' style pottery indicates a longer occupation than based on the ${ }^{14} \mathrm{C}$-dates (Fig. S2-A, Akkermans et al., 1981)). However, Yumuktepe (Fig. 3 site 22), where an hiatus in ${ }^{14} \mathrm{C}$-dates is present around 8200 $\mathrm{BP}$, is located in a favourable climate zone, while sites that show continuous occupation during the 8.2 ka event were present in current steppe areas $(<250 \mathrm{~mm})$, such as Tell Sabi Abyad (Fig. 3 site 36) and Çatalhöyük East (Fig. 3 site 20). Also sites in the extremely arid $(<100 \mathrm{~mm})$ Jordanian Eastern Desert continued to be used during the 8.2 ka event (Fig. 3 sites 57 and 59).

An absence of a clear and widespread decline is also reflected in the SPPs (Fig. 5), where no systematic changes in ${ }^{14} \mathrm{C}$-dates are found to occur at the time of either of the climate events. ${ }^{14} \mathrm{C}$-probabilities are somewhat low around 8200 cal BP in the Southern Levant (Fig. 5H), the Central Zagros (Fig. 5I), and Central Anatolia (Fig. 5E). This could partly reflect a slight effect of the $8.2 \mathrm{ka}$ event. However, the low probabilities are already observed at around $8700 / 8600$ cal BP in the Southern Levant, and from ca 8500 cal BP in the Central Zagros and Central Anatolia, and are therefore clearly not caused by the $8.2 \mathrm{ka}$ event. Moreover, the Central Anatolian SPPs are extremely biased, as they mostly consist of the ${ }^{14} \mathrm{C}$-dates from Çatalhöyük East $(n=190$ of a total of 293 quality-checked dates, Table S3). It has been suggested that this site was abandoned at around 8200 cal BP (Roberts 

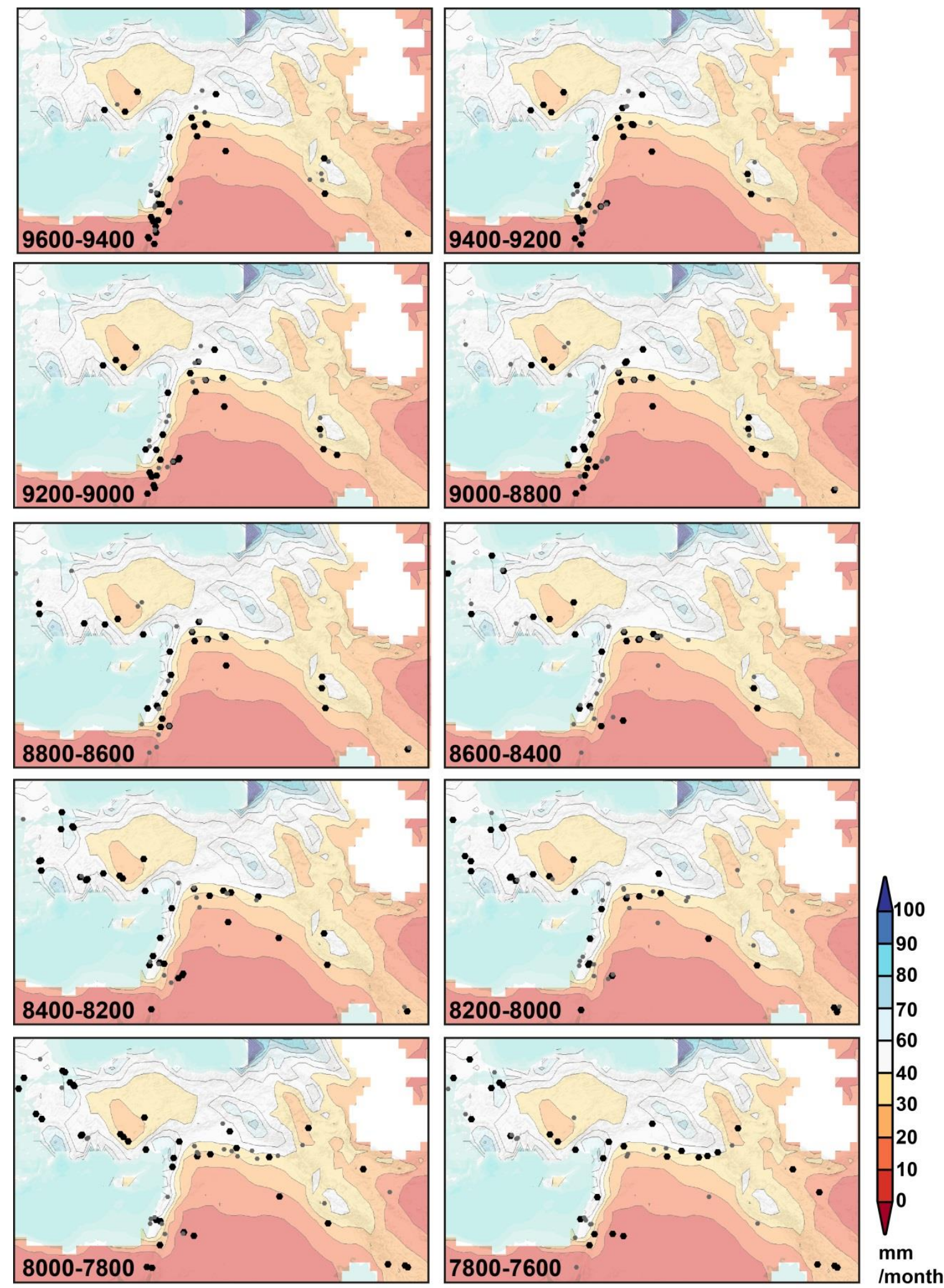

Figure 4 - Settlement distribution maps for 200 -year periods based on ${ }^{14} \mathrm{C}$-dates. The base map is derived from ArcGIS (sources: ESRI, USGS, NOAA), the precipitation map is derived from the KNMI Explorer tool (van Oldenborgh, 2015) and based on CRU 1901-2013 precipitation observations (Climatic Research Unit University of East Anglia, 2008). 
and Rosen, 2009; Weninger and Clare, 2011; Weninger et al., 2006, 2009), but new ${ }^{14} \mathrm{C}$ dates show that occupation continued until at least 8000 cal BP (Marciniak et al., 2015; Marciniak and Czerniak, 2007).

The decrease in probability values in the Southern Levant probably reflects the abandonment of larger LPPNB farming villages ('mega-sites'), which has previously been ascribed to the 8.2 ka event (Staubwasser and Weiss, 2006), but clearly occurs too early (Fig. 5-6, see also Fig. S2-B; see also Maher et al., 2011). Clare (2010) argues that these ${ }^{14} \mathrm{C}$-dates could be too early due to old wood effects and that the decline could be related to the general aridification starting at around $8600 \mathrm{cal}$ BP. On the other hand, FPPNB/PPNC site abandonment (Berger and Guilaine, 2009), which occurs closer to 8200 cal BP (but see section 5.3), does not yield much evidence for abandonment of sites (Fig. 3-5). As such, the abandonment of PPNB sites in the Levant clearly occurs too early to be caused by the 8.2 ka event.

The only region with a marked dip in ${ }^{14} \mathrm{C}$-date probabilities at around $8200 \mathrm{cal} \mathrm{BP}$, is Northern Mesopotamia, but only if the (rather relevant) site of Sabi Abyad is not taken into account (Fig. 5F and 6C). In any case, in this region the decline in ${ }^{14} \mathrm{C}$-probabilities starts between 8600 and 8400 cal BP already. Moreover, when ground-truthing the SPPs against evidence from individual sites (Fig. 3), it is clear that while each individual sites yielded fewer ${ }^{14} \mathrm{C}$-dates, the total number of sites remained stable throughout the event. It is therefore likely that the low probabilities are at least partly caused by a research bias, which has tended to disfavour the Late Neolithic period until recently (Akkermans and Schwartz, 2003). It is under discussion if the site of Sabi Abyad itself was continuously occupied throughout the 8.2 ka event (van der Plicht et al., 2011) or if there was a short occupation hiatus (Weninger et al., 2014). The latter hypothesis is, however, solely based on cemetery evidence. Our own analyses in OxCal show that it is currently not possible to solve this question by assessing only the ${ }^{14} \mathrm{C}$-dates (the OxCal Interval function indicates a gap of 9-99 years $(1 \sigma)$ or $0-158$ years $(2 \sigma)$ between phase $A 1$ and $B 8$, indicating that there may $(\geq 1)$ or may not (0) have been a hiatus, Table S4). Nonetheless, van der Plicht et al. (2011) note 


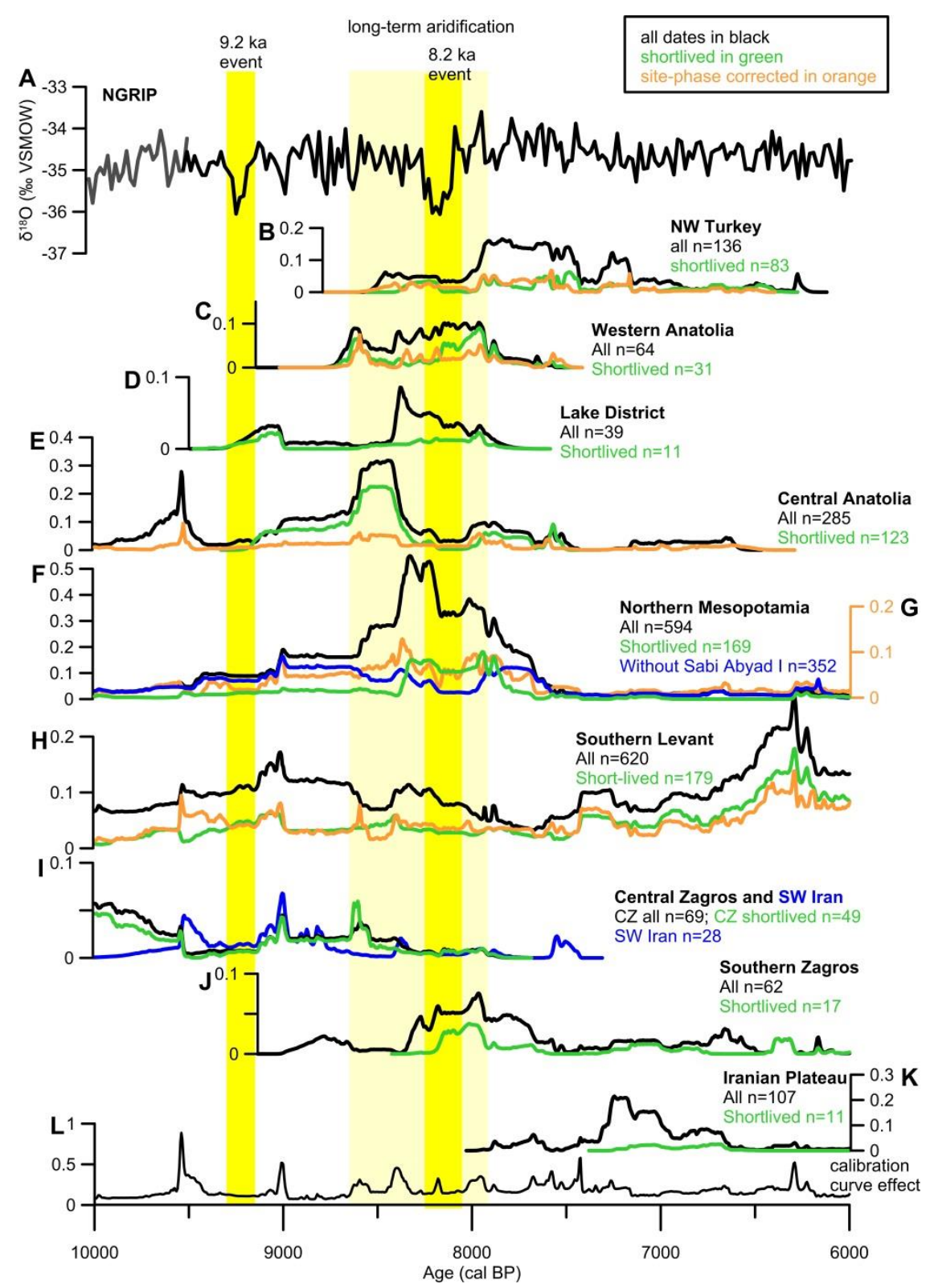

Figure 5 - Regional summed probability plots (SPPs) based on quality-checked ${ }^{14} \mathrm{C}$-dates for the period between 10000 and 6000 cal BP. The black line represents all quality-checked dates, the green line represents dates on short-lived samples (e.g. seeds, bone) only, and the orange line indicates site-phase corrected dates (Shennan and Edinborough, 2007). The plots are compared to the Greenland ice core NGRIP $\delta^{18} \mathrm{O}$ record (A) (Johnsen et al., 2001). Note that it is the area under the curve that gives the probability density, not the height of the curve itself. The 'calibration curve effect' $(L)$ is based on ${ }^{14} \mathrm{C}$-dates with an even spacing of five ${ }^{14} \mathrm{C}$-years; if no effect of the curve would be present, this would be a flat line. Comparison with this curve indicates if peaks or troughs in the SSPs are caused by the calibration effect. 


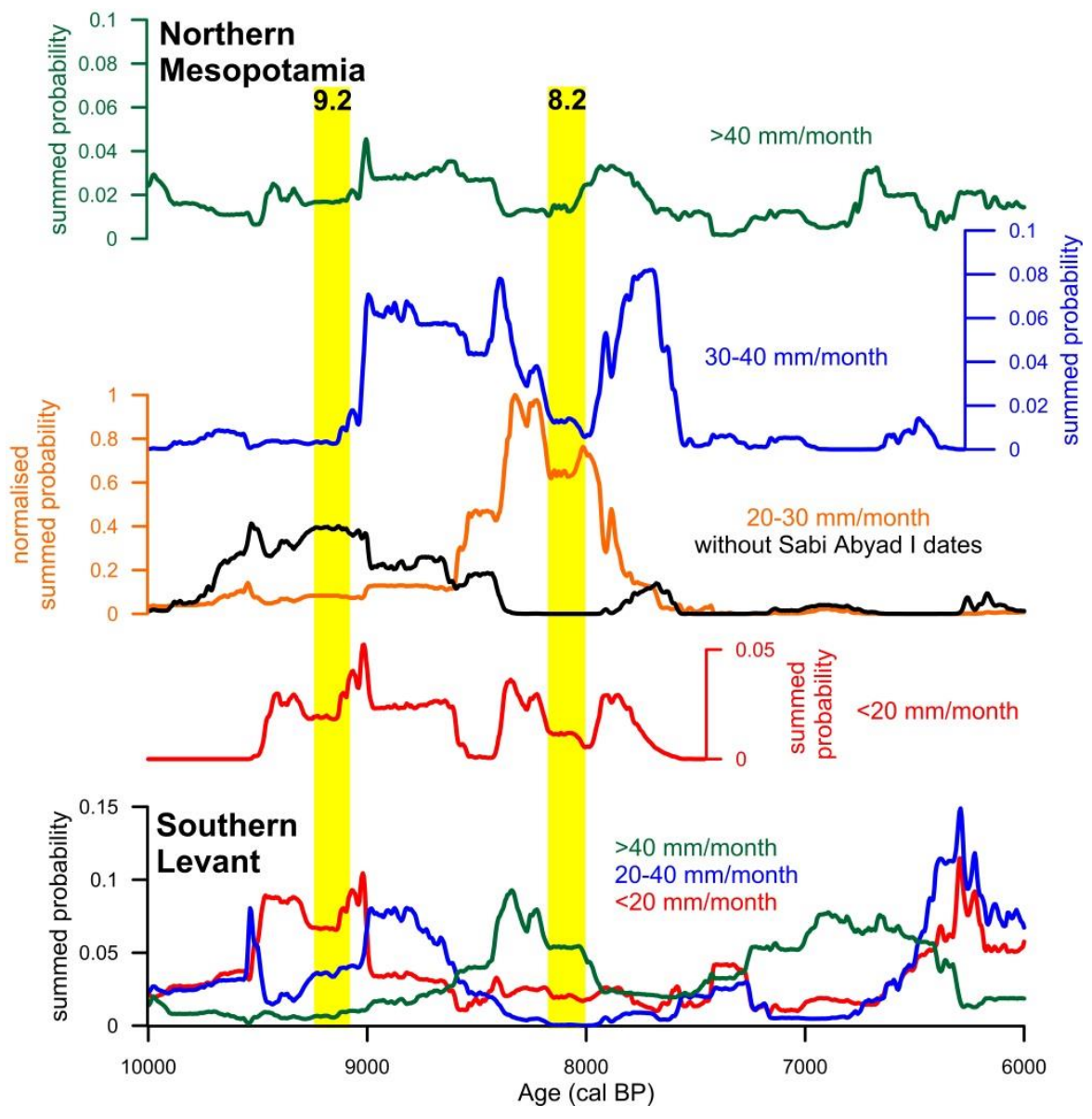

Figure 6 - Summed probability plots for different precipitation zones, assumed to reflect climate zones, in Northern Mesopotamia and the Southern Levant.

that there is an additional, undated phase B9 between A1 and B8, making continuity the more likely option. The latter is strongly supported by the excavators, who did not find evidence for a significant hiatus (Akkermans et al., 2014), showing the importance of taking into account both dating and archaeological evidence.

5.2 Is there evidence for migration?

The SPPs shown in Fig. 5 do not show evidence for widespread migration at either 9250 or $8200 \mathrm{cal}$ BP. The large majority of areas do not show a sudden increase in ${ }^{14} \mathrm{C}$-dates at or just after the start of either of the climatic events. Fig. 6 shows that this is the case not only on a regional scale, but also when taking different climate zones within regions into account, 
indicating no widespread intra-regional movement due to climatic changes associated with the 9.2 and 8.2 ka events.

There is no evidence of systematic movement during the 9.2 ka event (Fig. 4-5). The widely accepted shift of sites from the western to the eastern part of the Southern Levant (MPPNB-LPPNB transition) (Kuijt and Goring-Morris, 2002) is not apparent on the settlement distribution maps (Fig. 4), because of a lack of reliable (after quality-check) ${ }^{14} \mathrm{C}$-dates for many of the relevant sites. In any case, from ${ }^{14} \mathrm{C}$-dates that are available, this shift appears to have taken place around 9500 cal BP already (Benz, n.d.; see also Fig. S2-B). A migration into the desert has also been suggested to have occurred around this time (Gebel, 2002; Kuijt and Goring-Morris, 2002), and was potentially related to a climate shift, as it would allow for resource diversification. However, occupation in the desert happened before 9200 cal BP, while the first evidence for pastoralism there does not occur until after the 9.2 ka event (Fig. 7).

Figure 5A-D clearly shows that the earliest spread of the Neolithic to Western and Northwest Anatolia occurred several hundreds of years before the 8.2 ka event. This is in agreement with recently published studies (Brami, 2014; Düring, 2013; Weninger et al., 2014). Our new analysis shows that this holds up when looking at short-lived samples only, revealing that the pattern cannot be a result of an old wood effect. In addition, we also show that that this pattern remains clear when carefully checking ${ }^{14} \mathrm{C}$-dates from individual sites (section 5.3, Fig. S2). Also the second, main part of the Neolithic spread westwards, said to be characterised by dark coloured burnished ceramics (Özdoğan, 2011), did not coincide with the 8.2 ka event. Sites that are part of this so-called Archaic and Classic Fikirtepe culture (Özdoğan, 2011), fall temporarily far apart (see Erdoğu, 2001). The site of Ilıpınar (Fig. 3 site 5) is dated to start around 8000 cal BP (Roodenberg and Schier, 2001), thus post-dating the 8.2 ka event, while Menteşe (Fig. 3 site 6) and Barcin Höyük (Fig. 3 site 7) were occupied already from around 8400 cal BP, clearly pre-dating the event (Fig. 3 and S2). 
The postulated contribution of general aridification from around $8600 \mathrm{cal}$ BP to the spread of the Neolithic (Weninger and Clare, 2011; Weninger et al., 2014) is in general agreement with our set of quality-checked ${ }^{14} \mathrm{C}$-dates. The only exceptions are several charcoal samples from the site of Ulucak in Western Anatolia (Fig. S2; Fig. 3 site 9). Nonetheless, the appearance of Neolithic sites in Western and Northwestern Anatolia occurs over several hundred years (Fig. 5) and is therefore most likely not only caused by climate change.

In Iran, the first Neolithic occupations of the Northwest, the Plateau and the East occur after $8000 \mathrm{cal} \mathrm{BP}$, and are post-dating the 8.2 ka event (Fig. 5) $\left({ }^{14} \mathrm{C}\right.$-dates for Eastern Iran are not shown, as the currently available, quality-checked ${ }^{14} \mathrm{C}$-dates are all post-7500 cal BP, Table S1). It has been argued that the Early Holocene climate remained drier in Iran compared to other parts of Southwest Asia until about 6300 cal BP, with humidity gradually increasing during this period (Djamali et al., 2010; Stevens et al., 2001). Interestingly, the start of the occupation on the Iranian Plateau occurred from ca 8000 cal BP (long-lived samples) or 7500 cal BP (short-lived samples) (Fig. 5K) and may therefore be concurrent with increasing precipitation and humidity (Schmidt et al., 2011). This is an intriguing possibility, but more precisely dated local climate records and more archaeological ${ }^{14} \mathrm{C}$-dates on short-lived samples are needed to assess this.

In the Southern Zagros, ${ }^{14} \mathrm{C}$-probabilities increased at around 8200 cal BP (Fig. 3-5), although earlier occupation in the region has been attested at the site of Rahmatabad (Fig. 3 site 81; Fig. 5J) (Azizi Kharanaghi et al., 2013; Bernbeck et al., 2008). Nonetheless, it is possible that the occupation in the region increased as a result of the 8.2 ka event, even though it is, at least currently, not wetter than the regions where occupation was present previously, the Central Zagros or Southwestern Iran (Fig. 4). 


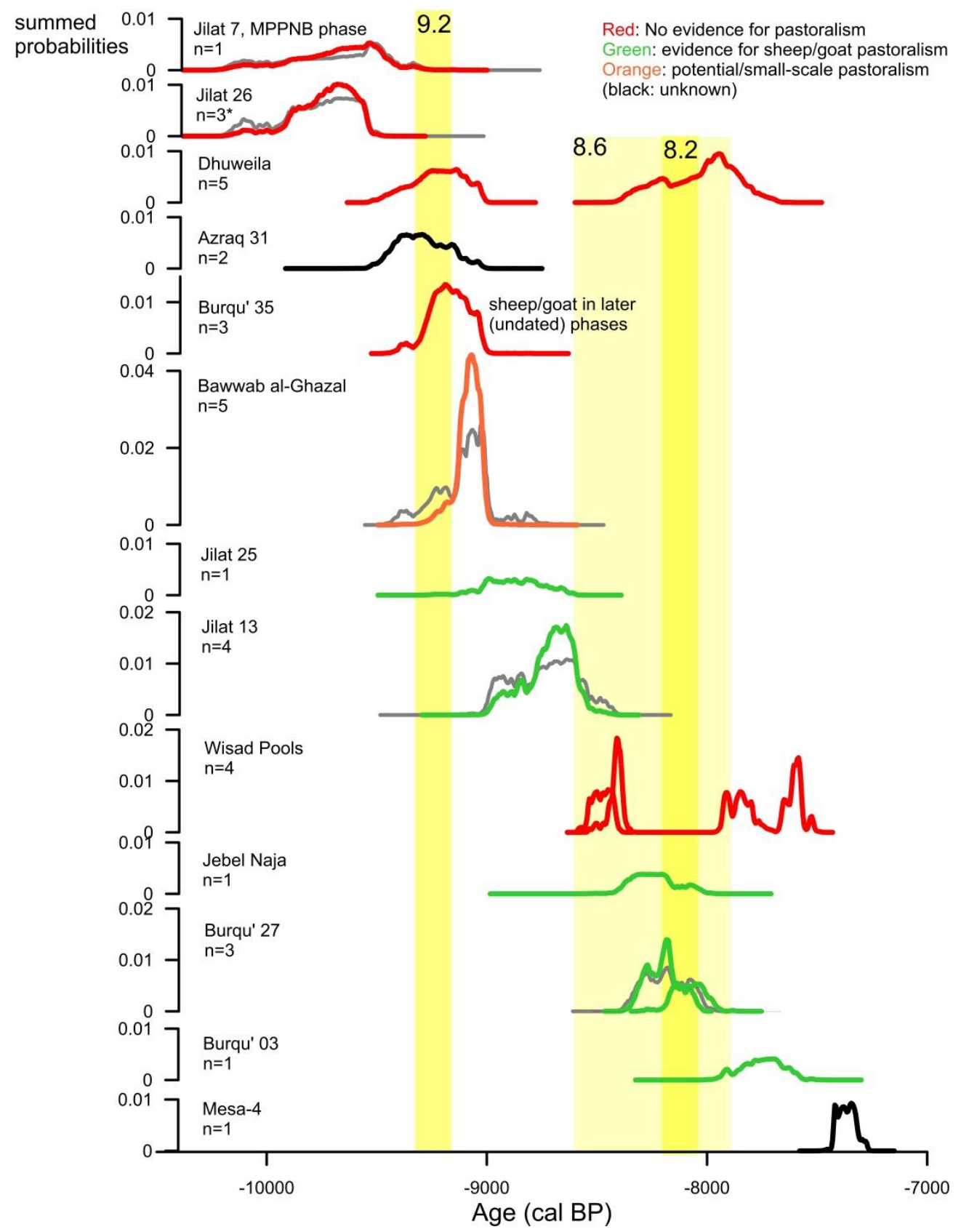

Figure 7 - Summed probability plots for sites in the Jordanian Desert. All quality-checked dates are shown, including those for sites with only a single ${ }^{14} \mathrm{C}$-date (for Jilat 26,3 dates are available which are in agreement with each other, but two of these have standard deviations of $\left.>100(110){ }^{14} \mathrm{C} \mathrm{yrs}\right)$. Red lines indicate sites without evidence for pastoralism (in the form of domesticated sheep/goat bones), green lines indicate sites with evidence for pastoralism, orange lines indicate sites where potential small-scale pastoralism was present, black lines indicate sites where no information on animal use is present. The coloured and black lines indicate SPPs of dates using boundaries in OxCal, while the grey lines in the background indicate the plots without boundaries (where no grey lines are visible, there was no difference). 


\subsection{Local adaptation?}

A third coping strategy is to adapt to climate change, for example by diversification of subsistence practices. To assess this, well-dated (>10 ${ }^{14} \mathrm{C}$-dates) and intensively studied archaeological sites that were occupied before and during the climate event of interest are needed.

Only five sites spanning the 9.2 ka event have over 10 quality-checked ${ }^{14} \mathrm{C}$-dates: Bouqras (Fig. 3 site 34) and Abu Hureyra (site 39) in Syria, 'Ain Ghazal (site 56) and Issaron (site 68) in the Southern Levant, and Tepe Guran (site 75) in Iran (Table S2). The ${ }^{14} \mathrm{C}$-dates for Tepe Guran are problematic as they are not in agreement with the stratigraphy and archaeology. The sites of Bouqras and Issaron lack a final publication, but their main (excavated) phases clearly continued without break throughout the 9.2 ka event (Fig. S2-A, C). As archaeological phases are defined by clear breaks in stratigraphy, construction, and/or material culture, the 9.2 ka event did apparently not coincide with major changes at these sites. Also at 'Ain Ghazal, the 9.2 ka event most likely falls in the middle of an archaeological phase, the LPPNB phase (Fig. S2-B), which appears to start between 9530 and $9350 \mathrm{cal}$ BP and not to end before $8900 \mathrm{cal} \mathrm{BP}$ (Table S5). While this is mostly based on dates from charcoal samples, it is supported by ${ }^{14} \mathrm{C}$-dates on seeds. Nonetheless, it should be noted that based on current ${ }^{14} \mathrm{C}$-dates, it is not impossible that the LPPNB at 'Ain Ghazal started around 9250 cal BP (Table S5). Overall, it can be concluded that there is currently no evidence for local changes at the time of the 9.2 ka event, but more evidence is needed.

To date, the following sites spanning the 8.2 ka event have been dated with $>10$ quality-checked ${ }^{14} \mathrm{C}$-dates and have published archaeological information: Tell Sabi Abyad (Fig. 3 site 36) in Syria, Yumuktepe (site 22), Çatalhöyük East (site 20), Ulucak (site 9), and Barcin Höyük (site 7) in Turkey, Sha'ar Hagolan (site 55) in Israel, and the Fars region (sites 79-83) in Iran.

Tell Sabi Abyad is very well dated and shows a multitude of changes at around 8200 cal BP, which coincide with the transition from level A1 to B8 (van der Plicht et al., 2011) 
(Fig. S2-D-E). These include a change in settlement location within the site, an increased importance of the drought-resistant species of sheep and goat, a decrease of pig, changes in secondary product use shown by the use of older animals and a steep increase in spindle whorl numbers, a change in ceramic styles, the increased use of painted pottery, and potentially a shift from household- to communal-sized storage areas (Akkermans, 2013; Nieuwenhuyse, 2013; Rooijakkers, 2012; Russell, 2010; van der Plicht et al., 2011). The increased importance of secondary products could reflect a diversification strategy, while changes in pottery styles and decoration could be indicative of changes in cooking practices and social changes, respectively (Nieuwenhuyse, 2013).

Nonetheless, it is not clear if these changes were caused by climatic change. Changes in animal bone, pottery, and spindle whorls already occurred in level A1 or even the earlier A2, which were dated mostly (just) before the event (A1 to 8280-8175 cal BP and A2 to $8335-8275$ cal BP, van der Plicht et al., 2011: Table 1). The changes have roots in previous levels and continue gradually over a long time: For example, painted pottery only occurs in small numbers in level A1 and B8, and gradually increases in importance thereafter, while secondary products only became important from the later level B3 onwards (Nieuwenhuyse, 2013; Russell, 2010). As such, it is difficult to relate these long-term trends specifically to the $8.2 \mathrm{ka}$ event. Also, some changes are difficult to link causally to an increasingly arid climate, such as an increase in the use of cattle (Russell, 2010) or the use of painted pottery. Moreover, the changes that were observed are not dramatic, e.g. the absolute changes in animal species counts are only slight.

At Yumuktepe (Fig. 3 site 22) in Southeastern Anatolia, there is a clear hiatus in ${ }^{14} \mathrm{C}$ dates around 8200 cal BP (in the modelled $1 \sigma$ range, no dates fall between 8266 and 8170 cal BP, Table S6, see Weninger et al., 2006). This coincides with the transition from the "Early" to "Middle Neolithic" phase at the site. It is possible that Yumuktepe was temporarily abandoned. However, the stratigraphy and material culture indicate continuity and only gradual cultural change from the Early to Middle phase, with a more profound change only occurring during the transition from the Middle to the Late phase (Caneva, 2012; Caneva 
and Sevin, 2004). This transition can be dated to 7900-7800 cal BP (modelled transition based on ${ }^{14} \mathrm{C}$-dates $95 \%$ certain not before 8000 cal BP, see Table S6), so clearly after the 8.2 ka event.

At Sha'ar Hagolan (Fig. 3 site 55), the PPNC-Pottery Neolithic (Yarmukian) tradition is documented. The Pottery Neolithic, or Late Neolithic, is characterized not only by the introduction of pottery and other material changes, but also by a continued decrease in large sites in favour of more, more dispersed and smaller sites (Banning et al., 1994), although Sha'ar Hagolan appears to be an exception in this respect. It is not impossible that this transition occurred around 8200 cal BP (see Clare, 2010), but current ${ }^{14} \mathrm{C}$-dates (albeit mostly on charcoal) indicate that it had probably already taken place between 8340 and $8255 \mathrm{cal}$ BP $(1 \sigma$, Fig. S2-F). This puts it before the 8.2 ka event, but after the start of the more general aridification. A pre-8200 cal BP end of the PPNC period is supported by ${ }^{14} \mathrm{C}$ dates from 'Ain Ghazal (Fig. 3 site 56), which do not span beyond 8500 cal BP (Fig. S2-B). In addition, recently published ${ }^{14} \mathrm{C}$-dates from Sha'ar Hagolan show that the Yarmukian did not end at the end of the 8.2 ka event, as previously argued (Clare, 2010), but continued into the next millennium (Garfinkel and Ben-Shlomo 2009, Fig. S2-F).

Also at Çatalhöyük East (Fig. 3 site 20), most changes occurred either before or after the 8.2 ka event. Levels V-I are clearly different from levels VI and before, with less densely packed occupation with more open spaces, less continuity in building place, an increased focus on the individual household in storage and production, and changes in lithics, ceramics, and figurines (Düring and Marciniak, 2006; Marciniak and Czerniak, 2007). However, these changes appear to occur already around 8400 cal BP (earliest beginning of level $\mathrm{V}$ at 8390 cal BP at $2 \sigma$, Cessford, 2005: Table 4.2), so preceding the 8.2 ka event by approximately 200 years, and post-dating the start of the general 8600 cal BP aridification by 200 years. The shift from the east to the west mound, on the other hand, clearly took place after the event, with occupation on the west mound not starting before 8000 cal BP, potentially overlapping with the last occupation on the east mound. 
At Ulucak (Fig. 3 site 9) and Barcin Höyük (Fig. 3 site 7) no changes contemporaneous with the 8.2 ka event appear to be present (Fig. S2-G-H). In both cases the event occurs in the middle of archaeological phases. Weninger and Clare (2011: 19) explain the lack of a break at Ulucak by the milder coastal climate of the site, which is also a possibility for Barcin Höyük.

In the Fars region in Iran there is some evidence for a change in lifestyle between the site dated during the event (Mushki, Fig. 3 site 83) and after (Jari, Fig. 3 site 82), with a more settled lifestyle after 8000 cal BP potentially as a result of more humid conditions after the climate event had ended (Niashiaki 2010). The ${ }^{14} \mathrm{C}$-dates so far match up, but dates from other sites are crucially needed to ascertain if the difference between these two sites is generally applicable to the region.

5.4 Why is there no evidence for an impact of the rapid climate events?

Based on our comprehensive analyses of ${ }^{14} \mathrm{C}$-dates and archaeological evidence, there is no clear evidence for large-scale site abandonment, migration, or uniform regional and local cultural changes. This is unexpected, especially for the $8.2 \mathrm{ka}$ event, which is one of the most pronounced rapid climate events of the Holocene. There are three potential reasons why clear evidence for the impact of the 9.2 and 8.2 ka events is absent from the archaeological record in Southwest Asia.

Firstly, climatic changes associated with the 9.2 and 8.2 ka events may not have been severe enough, as they were superimposed on a generally wetter Early Holocene (Arz et al., 2003; Göktürk et al., 2011; Robinson et al., 2006). While the 8.2 ka event was certainly a very pronounced climatic anomaly, the mean climate during the event was still more humid than the Late Holocene climate in Southwest Asia, as indicated by the Sofular and Soreq records (Fig. 1). While records and models indicate precipitation and temperature drops, its absolute effects may have not been sufficient to alter vegetation and harvests to such an extent to form a large problem in food supply in the region. 
Secondly, for the $8.2 \mathrm{ka}$ (but not for the $9.2 \mathrm{ka}$ ) event, it is possible that people, plants and animals had already adapted to more adverse climatic conditions. The climate had increasingly become more arid from around 8600 cal BP onwards, so societies likely had mechanisms in place to cope with this, such as diversification of resources and storage. Storage facilities were used at least from the PPNA period onwards (Kuijt and Finlayson, 2009), but increasing formalisation of storage has been argued to have developed, with household level storage during the Late Neolithic period (Bogaard et al., 2009), during which the $8.6 \mathrm{ka}$ aridification and finally the $8.2 \mathrm{ka}$ event took place. Storage was clearly important at the sites that continued throughout the $8.2 \mathrm{ka}$ event: household level storage was present at Çatalhöyük East (Bogaard et al., 2009), storage for extended families at Sha'ar Hagolan (Garfinkel and Ben-Shlomo, 2009; Garfinkel and Miller, 2002), and communal storage buildings came into existence after ca 8200 cal BP at Sabi Abyad (Akkermans, 2013; Russell, 2010).

Finally, the resilience of early farming societies should not be underestimated. The impact of a drought or climatic change depends on the strength of the hazard, but also the vulnerability of the society it acts upon, which in turn depends on various demographic, social, cultural, economic and political factors (Adger, 2006; Clare and Weninger, 2010; Gaillard, 2007; Garcia and Escudero, 1982; Garcia and Spitz, 1986). Present-day smallscale farming communities and pastoralists as well as 'traditional' societies are among the groups deemed especially vulnerable to climate change, because of low levels of technology and infrastructure (Bohle et al., 1994; Macchi et al., 2008; but see Gaillard, 2007). Probably as a consequence, preindustrial societies are considered very vulnerable too (Ambar and Scarasia-Mugnozza, 2012; Gonzalez-Samperiz et al., 2009). However, present-day smallscale communities are not comparable to past Neolithic farmers (Clare and Weninger, 2010).

Neolithic societies in Southwest Asia were, with some exceptions, frequently only small, consisting of perhaps a dozen households, and were dispersed in the landscape (Akkermans and Schwartz, 2003). They settled close to perennial water sources, with easy 
access to a variety of ecosystems. During the PPNB, a wide range of economic adaptations was present, varying from foragers and pastoralists (mainly in arid regions), fishers and farmers along the coasts, and farmers and herders and farmers and hunters in the Mediterranean and steppe areas (Goring-Morris and Belfer-Cohen, 2011). Communities did not solely rely on farming, but on diverse subsistence strategies, also making use of wild resources (Asouti and Fuller, 2013). For example at Çatalhöyük East, one of the sites that continued throughout the 8.2 ka event, wild plant resources like tubers, nuts and fruits as well as wild animals were an important addition to the diet throughout the site's history (Asouti and Fairbairn, 2002; Fairbairn et al., 2007; Fuller et al., 2014; Roberts and Rosen, 2009; Russell and Martin, 2005). At many other sites, wild plants and animals were also used as an addition to the diet, although with their importance and the used species varying between sites (Akkermans et al., 1983, 2006; Fairbairn et al., 2007; Kansa et al., 2009; Russell and Buitenhuis, 2008; but see Cappers, 2014). While wild resources appear to have been often only small additions to the diet, such small extras would have been important in times of stress.

Storage and resource diversification are just two (very relevant) examples, but they make clear that Southwest Asian Neolithic societies had the opportunity to be highly resilient to climate change. In fact, these relatively small-scale societies, where not a lot of specialisation had taken place, were potentially much less vulnerable to climate change than more 'complex' societies. More 'complex', specialized, and hierarchical societies are more interconnected and reliant on their social connections, which makes them less flexible to change when needed (Coombes and Barber, 2005). In addition, it has been argued that the more people have invested, the harder they will try not to change (Janssen et al., 2003), adding to the inflexibility of 'complex' societies.

\section{$6 \quad$ Conclusion}

In conclusion, there is no absolutely dated archaeological evidence for large-scale collapse or decline, or migration at the time of two of the most severe and rapid climatic changes of 
the Holocene. No more sites were abandoned than in other periods, and the sites that were potentially abandoned around the time of the rapid climate change events were not specifically located in more arid or colder areas. There is some evidence for local adaptation to the 8.2 ka event, such as at Tell Sabi Abyad in Northern Syria. Other sites that continue throughout the event do not show evidence for this, but none have been as precisely dated as Sabi Abyad. The lack of a large-scale, severe impact on Southwest Asian societies can be explained by the events being superimposed on the climatically favourable Early Holocene period, by already existing adaptation strategies due to long-term, gradual climate change, and/or by the resilience of the these early farming communities.

Our results are in contrast to many earlier studies, cited in section 1.1. Nonetheless, research is increasingly emerging that shows that prehistoric societies were resilient to climatic changes in a range of environments, such as in Iron Age Ireland (Armit et al., 2014). When 'collapse' is observed, this is rarely due to a single, climatic factor, but often involves a complex interplay of different factors (Butzer, 2012; Butzer and Endfield, 2012), as for example shown for the 'Maya Collapse' (Aimers, 2011; Dunning et al., 2012; Turner II and Sabloff, 2012). Similarly, in modern situations, we see that, for example, the decision to migrate is dependent on many different factors, including personal and family characteristics (Black et al., 2011b; Meze-Hausken, 2000).

The current data show clearly that there are no large-scale, regional-wide changes, such as mass abandonment of settlement groups at the time of the 9.2 and 8.2 ka climate events. However, our knowledge of the local impact of the climate events needs to be improved to assess past adaptation strategies. Firstly, more information is needed on local climate and environment. For example, the assertions that settlement on the Iranian Plateau was delayed due to unfavourable conditions (Schmidt et al., 2011), while settlement in the Fars region may have increased or changed during the 8.2 ka event (Nishiaki, 2010; Weeks, 2013), need to be checked against data from local climate records. Secondly, more sitespecific detailed studies focusing on the ecological bases and strategies, like conducted for Sabi Abyad, are needed. As we have clearly shown in this paper that there were no large- 
scale impacts of the Early Holocene rapid climate events, and that it is likely that the only effects were varied, local adaptations, high-resolution dating of archaeological sites, in combination with thorough studies of all environmental and material categories are essential. This site-specific 'bottom-up' approach is now the best way to further the debate. Such studies, in combination with existing publications, should be used to focus on certain 'phenomena': Taking all sites together, can we see changes in, for example, subsistence (animal use, plant use), or storage practices? This approach will be time consuming, but very worthwhile.

\section{Acknowledgements}

This research was funded by the University of Reading. We are very grateful to the two reviewers for their useful comments and to a variety of other people for informal discussions on the topic of this paper. The underlying research data can be found in the online

Supplementary Information and can be requested from the authors.

\section{References}

Abbo, S., Lev-Yadun, S., Gopher, A., 2010. Yield stability: an agronomic perspective on the origin of Near Eastern agriculture. Vegetation History and Archaeobotany 19, DOI 10.1007/s0033400009-00233-00337.

Abrantes, F., Voelker, A., Sierro, F.J., Naughton, F., Rodrigues, T., Cacho, I., Ariztegui, D., Brayshaw, D., Sicre, M.-A., Batista, L., 2012. Paleoclimate variability in the Mediterranean region, in: Lionello, P. (Ed.), The climate of the Mediterranean region: From the past to the future. Elsevier, Amsterdam, pp. 1-86.

Adger, W.N., 2006. Vulnerability. Global Environ Chang 16, 268-281.

Aimers, J., 2011. FORUM Societal collapse Drought and the Maya. Nature 479, 44-44.

Akkermans, P.A., Boerma, J.A.K., Clason, A.T., Hill, S.G., Lohof, E., Meiklejohn, C., Le Mière, M., Molgat, G.M.F., Roodenberg, J.J., Waterbolk-van Rooyen, W., Van Zeist, W., 1983. Bouqras revisited: Preliminary report on a project in Eastern Syria. Proceedings of the Prehistoric Society 49, 335-372.

Akkermans, P.A., Fokkens, H., Waterbolk, H.T., 1981. Stratigraphy, achitecture, and lay-out of Bouqras, in: Aurenche, O., Cauvin, M.-C., Sanlaville, P. (Eds.), Préhistoire du Levant: processus des changements culturels; hommage à Francis Hours. Maison de l'Orient Méditerranéen, Lyon.

Akkermans, P.M.M.G., 2013. Tell Sabi Abyad, or the Ruins of the White Boy. A short history of research into the Late Neolithic of Northern Syria, in: Bonatz, D., Martin, L. (Eds.), 100 Jahre archäologische Feldforschungen in Nordost-Syrien - eine Bilanz. Harrassowitz Verlag, Wiesbaden.

Akkermans, P.M.M.G., Brüning, M., Huigens, H., Nieuwenhuyse, O.P. (eds), 2014. Excavations at Late Neolithic Tell Sabi Abyad, Syria. The 1994-1999 field seasons. Brepols, Turnhout. 
Akkermans, P.M.M.G., Cappers, R., Cavallo, C., Nieuwenhuyse, O., Nilhamn, B., Otte, I.N., 2006. Investigating the early pottery Neolithic of northern Syria: New evidence from Tell Sabi Abyad. Am J Archaeol 110, 123-156.

Akkermans, P.M.M.G., Schwartz, G.M., 2003. The Archaeology of Syria: From Complex HunterGatherers to Early Urban Societies (ca. 16,000-300BC). Cambridge University Press, Cambridge.

Akkermans, P.M.M.G., van der Plicht, J., Nieuwenhuyse, O.P., Russell, A., Kaneda, A., Buitenhuis, H., 2010. Weathering climate change in the Near East: dating and Neolithic adaptations 8200 years ago. Antiquity Project Gallery 325.

Alley, R.B., Ágústsdóttir, A.M., 2005. The 8k event: cause and consequences of a major Holocene abrupt climate change. Quaternary Science Reviews 24, 1123-1149.

Alley, R.B., Mayewski, P.A., Sowers, T., Stuiver, M., Taylor, K.C., Clark, P.U., 1997. Holocene climatic instability: A prominent, widespread event 8200 yr ago. Geology 25, 483-486.

Ambar, I., Scarasia-Mugnozza, G., 2012. Foreword, in: Lionello, P. (Ed.), The climate of the Mediterranean Region: From the past to the future. Elsevier, Amsterdam, pp. xxi-xxiii.

Armit, I., Swindles, G.T., Becker, K., 2013. From dates to demography in later prehistoric Ireland? Experimental approaches to the meta-analysis of large C-14 data-sets. Journal of Archaeological Science 40, 433-438.

Armit, I., Swindles, G.T., Becker, K., Plunkett, G., Blaauw, M., 2014. Rapid climate change did not cause population collapse at the end of the European Bronze Age. P Natl Acad Sci USA.

Arz, H.W., Lamy, F., Patzold, J., Muller, P.J., Prins, M., 2003. Mediterranean Moisture Source for an Early-Holocene Humid Period in the Northern Red Sea. Science 300, 118-121.

Asouti, E., Fairbairn, A., 2002. Subsistence economy in Central Anatolia during the Neolithic: the archaeobotanical evidence, in: Gérard, F., Thissen, L. (Eds.), The Neolithic of Central Anatolia. Internal developments and external relations during the 9th - 6th millennia cal BC. Ege Yainlari, Istanbul, pp. 181-192.

Asouti, E., Fuller, D.Q., 2013. A contextual approach to the emergence of agriculture in Southwest Asia. Current Anthropology 54, 299-345.

Azizi Kharanaghi, H., Fazeli Nashli, H., Nishiaki, Y., 2013. Tepe Rahmatabad: A Pre-Pottery and Pottery Neolithic site in Fars Province, in: Matthews, R., Fazeli Nashli, H. (Eds.), The Neolithisation of Iran. The formation of new societies. Oxbow, Oxford, pp. 108-123.

Banning, E.B., Rahimi, D., Siggers, J., 1994. The Late Neolithic of the Southern Levant: Hiatus, Settlement Shift or Observer Bias? The Perspective from Wadi Ziqlab. Paléorient 20, 151-164.

Bar-Matthews, M., Ayalon, A., Gilmour, M., Matthews, A., Hawkesworth, C., 2003. Sea-land oxygen isotopic relationships from planktonic forminifera and speleothems in the Eastern Mediterranean region and their implication for paleorainfall during interglacial intervals. Geochimica et Cosmochimica Acta 67, 3181-3199.

Bar-Matthews, M., Ayalon, A., Kaufman, A., Wasserburg, G.J., 1999. The Eastern Mediterranean paleoclimate as a reflection of regional events: Soreq cave, Israel. Earth and Planetary Science Letters 166, 85-95.

Bar-Yosef, O., Belfer-Cohen, A., 2002. Facing environmental crisis. Societal and cultural changes at the transition from the Younger Dryas to the Holocene in the Levant, in: Cappers, R.T.J., Botteman, S. (Eds.), The Dawn of Farming in the Near East. ex oriente, Berlin, pp. 55-66.

Barber, D.C., Dyke, A., Hillaire-Marcel, C., Jennings, A.E., Andrews, J.T., Kerwin, M.W., Bilodeau, G., McNeely, R., Southon, J., Morehead, M.D., Gagnon, J.M., 1999. Forcing of the cold event of 8,200 years ago by catastrophic drainage of Laurentide lakes. Nature 400, 344-348.

Belfer-Cohen, A., Goring-Morris, A.N., 2011. Becoming Farmers: The Inside Story. Current Anthropology 52, S209-S220.

Benz, M., n.d. PPND - The Platform for Neolithic Radiocarbon Dates. Ex Oriente, http://www.exoriente.org/associated_projects/ppnd.php.

Berger, J.F., Guilaine, J., 2009. The 8200 cal BP abrupt environmental change and the Neolithic transition: A Mediterranean perspective. Quaternary International 200, 31-49.

Bernbeck, R., 1994. Die Auflösung der Häuslichen Produktionsweise: Das Beispiel Mesopotamiens. Dietrich Reimer Verlag, Berlin.

Bernbeck, R., Pollock, S., Fazeli Nashli, H., 2008. Rahmatabad: Dating the Aceramic Neolithic in Fars Province. Neo-Lithics 1/08, 37-39.

Biehl, P.F., 2012. Rapid change versus long-term social change during the Neolithic-Chalcolithic transition in Central Anatolia. Interdisciplinaria Archaeologica - Natural Sciences in Archaeology 3, 75-83. 
Black, E., Brayshaw, D., Black, S., Rambeau, C., 2011a. Using proxy data, historical climate data and climate models to investigate aridification during the Holocene, in: Mithen, S., Black, E. (Eds.), Water, Life, and Civilisation: Climate, Environment and Society in the Jordan Valley. Cambridge University Press, Cambridge, pp. 105-112.

Black, R., Adger, W.N., Arnell, N.W., Dercon, S., Geddes, A., Thomas, D.S.G., 2011b. The effect of environmental change on human migration. Global Environ Chang 21, S3-S11.

Block, S., Webb, P., 2001. The dynamics of livelihood diversification in post-famine Ethiopia. Food Policy 26, 333-350.

Bogaard, A., Charles, M., Twiss, K.C., Fairbairn, A., Yalman, N., Filipovic, D., Demirergi, G.A., Ertug, F., Russell, N., Henecke, J., 2009. Private pantries and celebrated surplus: storing and sharing food at Neolithic Catalhoyuk, Central Anatolia. Antiquity 83, 649-668.

Bohle, H.G., Downing, T.E., Watts, M.J., 1994. Climate-Change and Social Vulnerability - toward a Sociology and Geography of Food Insecurity. Global Environ Chang 4, 37-48.

Böhner, U., Schyle, D., 2002-2006. radiocarbon CONTEXT database 2002-2006.

Bonsall, C., Macklin, M.G., Payton, R.W., Boroneant, A., 2002. Climate, floods and river gods: environmental change and the Meso-Neolithic transition in southeast Europe. Before Farming 3/4, 1-12.

Bordon, A., Peyron, O., Lezine, A.M., Brewer, S., Fouache, E., 2009. Pollen-inferred Late-Glacial and Holocene climate in southern Balkans (Lake Maliq). Quaternary International 200, 19-30.

Borrell, F., 2007. From PPNB to PN: Chipped stone industries of the Middle Euphrates Valley. New data, new interpretations. Neo-Lithics 1/07, 33-37.

Bowman, S., 1990. Radiocarbon dating. British Museum Publications, London.

Brami, M., 2014. A graphical simulation of the 2,000-year lag in Neolithic occupation between Central Anatolia and the Aegean basin. Archaeol Anthropol Sci, 1-9.

Bronk Ramsey, C., 2009a. Bayesian analysis of radiocarbon dates. Radiocarbon 51, 337-360.

Bronk Ramsey, C. 2009b. Dealing with outliers and offsets in radiocarbon dating. Radiocarbon 51, 1023-1045.

Budja, M., 2007. The 8200 calBP 'climate event' and the process of neolithisation in south-eastern Europe. Documenta Praehistorica XXXIV, 191-201.

Butzer, K.W., 2012. Collapse, environment, and society. P Natl Acad Sci USA 109, 3632-3639.

Butzer, K.W., Endfield, G.H., 2012. Critical perspectives on historical collapse. P Natl Acad Sci USA 109, 3628-3631.

Caneva, I., 2012. Mersin-Yumuktepe in the seventh millennium BC: an updated view, in: Özdoğan, M., Başgelen, N., Kuniholm, P. (Eds.), The Neolithic in Turkey, vol. 3: Central Anatolia. Archaeology and Art Publications, Istanbul, pp. 1-29.

Caneva, I., Sevin, V., 2004. Mersin-Yumuktepe: a reappraisal. Congedo, Galatina.

Cappers, R.T.J., 2014. The cultivated and wild plant remains, in: Akkermans, P.M.M.G., Brüning, M.L., Huigens, H.O., Nieuwenhuyse, O.P. (Eds.), Excavations at Late Neolithic Tell Sabi Abyad, Syria. The 1994-1999 field seasons. Brepols, Turnhout, pp. 233-246.

Carmi, I., Segal, D., Goringmorris, A.N., Gopher, A., 1994. Dating the Prehistoric Site Nahal-Issaron in the Southern Negev, Israel. Radiocarbon 36, 391-398.

Cessford, C., 2005. Absolute dating at Çatalhöyük, in: Hodder, I. (Ed.), Changing materialities at Çatalhöyük: reports from the 1995-99 seasons. McDonal Institute for Archaeological Research/British Institute at Ankara, Cambridge/London, pp. 65-99.

Cheng, H., Fleitmann, D., Edwards, R.L., Wang, X.F., Cruz, F.W., Auler, A.S., Mangini, A., Wang, Y.J., Kong, X.G., Burns, S.J., Matter, A., 2009. Timing and structure of the $8.2 \mathrm{kyr}$ BP event inferred from delta O-18 records of stalagmites from China, Oman, and Brazil. Geology 37, 1007-1010.

Çilingiroğlu, A., Çevik, Ö., Çilingiroğlu, Ç., 2012. Ulucak Höyük. Towards understanding the early farming communities of Middle West Anatolia: the contribution of Ulucak, in: Özdoğan, M., Başgelen, N., Kuniholm, P. (Eds.), The Neolithic in Turkey, vol. 4. Archaeology and Art Publications, Istanbul.

Clare, L., 2010. Pastoral clashes: Conflict risk and mitigation at the Pre-Pottery Neolithic transition in the Southern Levant. Neo-Lithics 1/10, 13-31.

Clare, L., Weninger, B., 2010. Social and biophysical vulnerability of prehistoric societies to Rapid Climate Change. Documenta Praehistorica XXXVII, 283-292.

Clarke, G., Leverington, D., Teller, J., Dyke, A., 2003. Superlakes, megafloods, and abrupt climate change. Science 301, 922-923. 
Clarke, G.K.C., Leverington, D.W., Teller, J.T., Dyke, A.S., 2004. Paleohydraulics of the last outburst flood from glacial Lake Agassiz and the 8200 BP cold event. Quaternary Science Reviews 23, 389-407.

Climatic Research Unit University of East Anglia, Climatic Research Unit, Jones, P.D., Harris, I., 2008. Climatic Research Unit (CRU) time-series datasets of variations in climate with variations in other phenomena. NCAS British Atmospheric Data Centre, http://catalogue.ceda.ac.uk/uuid/3f8944800cc48e1cbc29a5ee12d8542d.

Contreras, D.A., Meadows, J., 2014. Summed radiocarbon calibrations as a population proxy: a critical evaluation using a realistic simulation approach. Journal of Archaeological Science 52, 591-608.

Coombes, P., Barber, K., 2005. Environmental determinism in Holocene research: causality or coincidence? Area 37, 303-311.

Dean, J.R., 2014. Stable isotope analysis and U-Th dating of Late Glacial and Holocene lacustrine sediments from Central Turkey (unpublished PhD thesis). University of Nottingham, Nottingham.

deMenocal, P.B., 2001. Cultural Responses to Climate Change During the Late Holocene. Science 292, 667-673.

Djamali, M., Akhani, H., Andrieu-Ponel, V., Braconnot, P., Brewer, S., de Beaulieu, J.L., Fleitmann, D., Fleury, J., Gasse, F., Guibal, F., Jackson, S.T., Lezine, A.M., Medail, F., Ponel, P., Roberts, N., Stevens, L., 2010. Indian Summer Monsoon variations could have affected the earlyHolocene woodland expansion in the Near East. Holocene 20, 813-820.

Dormoy, I., Peyron, O., Nebout, N.C., Goring, S., Kotthoff, U., Magny, M., Pross, J., 2009. Terrestrial climate variability and seasonality changes in the Mediterranean region between 15000 and 4000 years BP deduced from marine pollen records. Clim Past 5, 615-632.

Dunning, N.P., Beach, T.P., Luzzadder-Beach, S., 2012. Kax and kol: Collapse and resilience in lowland Maya civilization. P Natl Acad Sci USA 109, 3652-3657.

Düring, B.S., 2013. Breaking the Bond: Investigating The Neolithic Expansion in Asia Minor in the Seventh Millennium BC. Journal of World Prehistory 26, 75-100.

Düring, B.S., Marciniak, A., 2006. Households and communities in the central Anatolian Neolithic. Archaeological Dialogues 12, 165-187.

Eastwood, W.J., Leng, M.J., Roberts, N., Davis, B., 2007. Holocene climate change in the eastern Mediterranean region: a comparison of stable isotope and pollen data from Lake Golhisar, southwest Turkey. J Quaternary Sci 22, 327-341.

Ellison, C.R.W., Chapman, M.R., Hall, I.R., 2006. Surface and deep ocean interactions during the cold climate event 8200 years ago. Science 312, 1929-1932.

Emeis, K.C., Struck, U., Schulz, H.M., Rosenberg, R., Bernasconi, S., Erlenkeuser, H., Sakamoto, T., Martinez-Ruiz, F., 2000. Temperature and salinity variations of Mediterranean Sea surface waters over the last 16,000 years from records of planktonic stable oxygen isotopes and alkenone unsaturation ratios. Palaeogeography Palaeoclimatology Palaeoecology 158, 259280.

Erdoğu, B., 2001. Neolithic and Chalcolithic cultures in Turkish Thrace (unpublished PhD thesis). Durham University, http://etheses.dur.ac.uk/3994/.

Fairbairn, A., Martinoli, D.E., Butler, A., Hillman, G., 2007. Wild plant seed storage at Neolithic Çatalhöyük East, Turkey. Vegetation History and Archaeobotany 16, 467-479.

Fernandez Lopez de Pablo, J., Gomez Puche, M., 2009. Climate change and population dynamics during the Late Mesolithic and the Neolithic transition in Iberia. Documenta Praehistorica XXXVI, 67-96.

Fernandez Lopez de Pablo, J., Jochim, M.A., 2010. The impact of the 8,200 cal BP climatic event on human mobility strategies during the Iberian Late Mesolithic. Journal of Anthropological Research 66, 39-68.

Finlayson, B., Mithen, S., Smith, S., 2011. On the Edge: Southern Levantine Epipalaeolithic - Neolithic Chronological succession. Levant 43, 127-138.

Fleitmann, D., Burns, S.J., Mangini, A., Mudelsee, M., Kramers, J., Villa, I., Neff, U., Al-Subbary, A.A., Buettner, A., Hippler, D., Matter, A., 2007. Holocene ITCZ and Indian monsoon dynamics recorded in stalagmites from Oman and Yemen (Socotra). Quaternary Science Reviews 26, 170-188.

Fleitmann, D., Burns, S.J., Mudelsee, M., Neff, U., Kramers, J., Mangini, A., Matter, A., 2003. Holocene forcing of the Indian monsoon recorded in a stalagmite from Southern Oman. Science 300, 1737-1739. 
Fleitmann, D., Mudelsee, M., Burns, S.J., Bradley, R.S., Kramers, J., Matter, A., 2008. Evidence for a widespread climatic anomaly at around 9.2 ka before present. Paleoceanography 23.

Fuller, D., Bogaard, A., Charles, M., Filipovic, D., 2014. Macro- and micro- botanical remains from the 2013 and 2014 seasons, in: Haddow, S.D. (Ed.), Çatalhöyük 2014 archive report, www.catalhoyuk.com, pp. 118-135.

Gaillard, J.-C., 2007. Resilience of traditional societies in facing natural hazards. Disaster Prevention and Management 16, 522-544.

Garcia, R.V., Escudero, J.C., 1982. Drought and Man: The 1972 case history. Volume 2: The constant catastrophe: Malnutrition, famines and drought. Pergamon Press, Oxford.

Garcia, R.V., Spitz, P., 1986. Drought and Man: The 1972 case history. Volume 3: The roots of catastrophe. Pergamom Press, Oxford.

Garfinkel, Y., Ben-Shlomo, D., 2009. Sha'ar Hagolan. Volume 2: The rise of urban concepts in the ancient Near East, Qedem reports. The Institute of Archaeology, the Hebrew University of Jerusalem, Jerusalem.

Garfinkel, Y., Miller, M.A., 2002. Sha'ar Hagolan, Volume 1: Neolithic Art in Context. Oxbow Books, Oxford.

Gebel, H.G.K., 2002. Subsistenzformen, Siedlungsweisen und Prozesse des sozialen Wandels vom akeramischen bis zum keramischien Neolithikum, Philosophischen Fakultäten. Albert-LudwigsUniversität zu Freiburg i. Breisgau.

Gehlen, B., Schön, W., 2005. Klima und Kulturwandel: Mögliche Folgen dest "6200-Events" in Europa, in: Gronenborn, D. (Ed.), Klimaveränderung and Kulturwandel in Neolithischen Gesellschaften Mitteleuropas, 6700-2200 v. Chr. . Römisch-Germanisches Zentralmuseum, Mainz, pp. 53-74.

Gerritsen, F., Özbal, R., Thissen, L., 2013a. Barcın Höyük. The beginnings of farming in the Marmara Region, in: Özdoğan, M., Başgelen, N., Kuniholm, P. (Eds.), The Neolithic in Turkey, vol. 5. Archaeology and Art Publications, Istanbul, pp. 93-112.

Gerritsen, F., Özbal, R., Thissen, L., 2013b. The earliest Neolithic levels at Barcın Höyük, Northwestern Turkey. Anatolica 39, 53-92.

Gillespie, R., 1984. Radiocarbon User's Handbook. Oxford University Committee for Archaeology, Oxford.

Gleick, P.H., 2014. Water, Drought, Climate Change, and Conflict in Syria. Weather Clim Soc 6, 331340.

Göktürk, O.M., Fleitmann, D., Badertscher, S., Cheng, H., Edwards, R.L., Leuenberger, M., Fankhauser, A., Tuysuz, O., Kramers, J., 2011. Climate on the southern Black Sea coast during the Holocene: implications from the Sofular Cave record. Quaternary Science Reviews 30, 2433-2445.

Gonzalez-Samperiz, P., Utrilla, P., Mazo, C., Valero-Garces, B., Sopena, M.C., Morellon, M., Sebastian, M., Moreno, A., Martinez-Bea, M., 2009. Patterns of human occupation during the early Holocene in the Central Ebro Basin (NE Spain) in response to the 8.2 ka climatic event. Quaternary Research 71, 121-132.

Goring-Morris, A.N., Belfer-Cohen, A., 2011. Neolithization Processes in the Levant:The Outer Envelope. Current Anthropology 52, S195-S208.

Gronenborn, D., 2009. Climate fluctuations and trajectories to complexity in the Neolithic: towards a theory. Doc Praehist 36, 97-110.

Halstead, P., O'Shea, J., 1989. Bad year economics: Cultural responses to risk and uncertainty. Cambridge University Press, Cambridge.

Hormes, A., Blaauw, M., Dahl, S.O., Nesje, A., Possnert, G., 2009. Radiocarbon wiggle-match dating of proglacial lake sediments - Implications for the 8.2 ka event. Quat Geochronol 4, 267-277.

Huffman, T.N., 2009. A cultural proxy for drought: ritual burning in the Iron age of Southern Africa. Journal of Archaeological Science 36, 991-1005.

Janssen, M.A., Kohler, T.A., Scheffer, M., 2003. Sunk-cost effects and vulnerability to collapse in ancient societies. Curr Anthropol 44, 722-728.

Johnsen, S.J., DahlJensen, D., Gundestrup, N., Steffensen, J.P., Clausen, H.B., Miller, H., MassonDelmotte, V., Sveinbjornsdottir, A.E., White, J., 2001. Oxygen isotope and palaeotemperature records from six Greenland ice-core stations: Camp Century, Dye-3, GRIP, GISP2, Renland and NorthGRIP. J Quaternary Sci 16, 299-307.

Kaniewski, D., Van Campo, E., Guiot, J., Le Burel, S., Otto, T., Baeteman, C., 2013. Environmental roots of the Late Bronze Age Crisis. PLoS ONE 8, e71004.

Kansa, S.W., Kennedy, A., Campbell, S., Carter, E., 2009. Resource Exploitation at Late Neolithic Domuztepe Faunal and Botanical Evidence. Current Anthropology 50, 897-914. 
Kelley, C.P., Mohtadi, S., Cane, M.A., Seager, R., Kushnir, Y., 2015. Climate change in the Fertile Crescent and implications of the recent Syrian drought. P Natl Acad Sci USA 112, 3241-3246.

Klitgaard-Kristensen, D., Sejrup, H.P., Haflidason, H., Johnsen, S., Spurk, M., 1998. A regional 8200 cal. yr BP cooling event in northwest Europe, induced by final stages of the Laurentide icesheet deglaciation? J Quaternary Sci 13, 165-169.

Kobashi, T., Severinghaus, J.P., Brook, E.J., Barnola, J.M., Grachev, A.M., 2007. Precise timing and characterization of abrupt climate change 8200 years ago from air trapped in polar ice. Quaternary Science Reviews 26, 1212-1222.

Kotthoff, U., Pross, J., Muller, U.C., Peyron, O., Schmiedl, G., Schulz, H., Bordon, A., 2008. Climate dynamics in the borderlands of the Aegean Sea during formation of sapropel S1 deduced from a marine pollen record. Quaternary Science Reviews 27, 832-845.

Kuijt, I., Finlayson, B., 2009. Evidence for food storage and predomestication granaries 11,000 years ago in the Jordan Valley. PNAS 106, 10966-10970.

Kuijt, I., Goring-Morris, N., 2002. Foraging, Farming, and Social Complexity in the Pre-Pottery Neolithic of the Southern Levant: A Review and Synthesis. Journal of World Prehistory 16, 361 440.

Leppard, T.P., 2014. Mobility and migration in the Early Neolithic of the Mediterranean: questions of motivation and mechanism. World Archaeology 46, 484-501.

Leslie, P., McCabe, J.T., 2013. Response Diversity and Resilience in Social-Ecological Systems. Curr Anthropol 54, 114-143.

Macchi, M., Oviedo, G., Gotheil, S., Cross, K., Boedhihartono, A., Wolfangel, C., Howell, M., 2008. Indigenous and traditional peoples and climate change. IUCN, http://cmsdata.iucn.org/downloads/indigenous_peoples_climate_change.pdf.

Maher, L.A., Banning, E.B., Chazan, M., 2011. Oasis or Mirage? Assessing the Role of Abrupt Climate Change in the Prehistory of the Southern Levant. Cambridge Archaeological Journal 21, 1-29.

Marciniak, A., Baranski, M.Z., Bayliss, A., Czerniak, L., Goslar, T., Southon, J., Taylor, R.E., 2015. Fragmenting times: interpreting a Bayesian chronology for the Late Neolithic occupation of Çatalhöyük East, Turkey. Antiquity 89, 154-176.

Marciniak, A., Czerniak, L., 2007. Social transformations in the Late Neolithic and Early Chalcolithic periods in central Anatolia. Anatolian Studies 57, 115-130.

Marino, G., Rohling, E.J., Sangiorgi, F., Hayes, A., Casford, J.L., Lotter, A.F., Kucera, M., Brinkhuis, H., 2009. Early and middle Holocene in the Aegean Sea: interplay between high and low latitude climate variability. Quaternary Science Reviews 28, 3246-3262.

Mercone, D., Thomson, J., Abu-Zied, R.H., Croudace, I.W., Rohling, E.J., 2001. High-resolution geochemical and micropalaeontological profiling of the most recent eastern Mediterranean sapropel. Mar Geol 177, 25-44.

Mercone, D., Thomson, J., Croudace, I.W., Siani, G., Paterne, M., Troelstra, S., 2000. Duration of S1, the most recent sapropel in the eastern Mediterranean Sea, as indicated by accelerator mass spectrometry radiocarbon and geochemical evidence. Paleoceanography 15, 336-347.

Meze-Hausken, E., 2000. Migration caused by climate change: How vulnerable are people in dryland areas. Migration and Adaptation Strategies for Global Change 5, 379-406.

Migowski, C., Stein, M., Prasad, S., Negendank, J.F.W., Agnon, A., 2006. Holocene climate variability and cultural evolution in the Near East from the Dead Sea sedimentary record. Quaternary Research 66, 421-431.

Mook, W.G., Waterbolk, H.T., 1985. Handbook for Archaeologists N. 3: Radiocarbon dating. European Science Foundation, Strasbourg.

Morrill, C., LeGrande, A.N., Renssen, H., Bakker, P., Otto-Bliesner, B.L., 2013. Model sensitivity to North Atlantic freshwater forcing at $8.2 \mathrm{ka}$. Clim Past 9, 955-968.

Nieuwenhuyse, O., 2013. The social uses of decorated ceramics in Late Neolithic Mesopotamia, in: Nieuwenhuyse, O.P., Bernbeck, R., Akkermans, P.M.M.G., Rogash, J. (Eds.), Interpreting the Late Neolithic of Upper Mesopotamia. Brepols, Turnhout, pp. 135-145.

Nishiaki, Y., 2010. A radiocarbon chronology for the Neolithic settlement of Tall-i Mushki, Marv Dasht Plain, Fars, Iran. Iran 48, 1-10.

Olsson, I.U., 2009. Radiocarbon dating history: early days, questions, and problems met. Radiocarbon 51, 1-43.

Özdoğan, M., 2011. Archaeological Evidence on the Westward Expansion of Farming Communities from Eastern Anatolia to the Aegean and the Balkans. Current Anthropology 52, S415-S430.

Peyron, O., Goring, S., Dormoy, I., Kotthoff, U., Pross, J., de Beaulieu, J.L., Drescher-Schneider, R., Vanniere, B., Magny, M., 2011. Holocene seasonality changes in the central Mediterranean 
region reconstructed from the pollen sequences of Lake Accesa (Italy) and Tenaghi Philippon (Greece). Holocene 21, 131-146.

Pross, J., Kotthoff, U., Muller, U.C., Peyron, O., Dormoy, I., Schmiedl, G., Kalaitzidis, S., Smith, A.M., 2009. Massive perturbation in terrestrial ecosystems of the Eastern Mediterranean region associated with the $8.2 \mathrm{kyr}$ BP climatic event. Geology 37, 887-890.

Rasmussen, S.O., Vinther, B.M., Clausen, H.B., Andersen, K.K., 2007. Early Holocene climate oscillations recorded in three Greenland ice cores. Quaternary Science Reviews 26, 19071914.

Rasmussen, S.O., Bigler, M., Blockley, S.P., Blunier, T., Buchardt, S.L., Clausen, H.B., Cvijanovic, I., Dahl-Jensen, D., Johnsen, S.J., Fischer, H., Gkinis, V., Guillevic, M., Hoek, W.Z., Lowe, J.J., Pedro, J.B., Popp, T., Seierstadt, I.K., Steffensen, J.P., Svensson, A.M., Vallelonga, P., Vinther, B.M., Walker, M.J.C., Wheatley, J.J., Winstrup, M., 2014. A stratigraphic framework for abrupt climate changes during the Last Glacial period based on three synchronized Greenland ice-core records: refining and extending the INTIMATE event stratigraphy. Quaternary Science Reviews 106, 14-28.

Reimer, P.J., Bard, E., Bayliss, A., Beck, J.W., Blackwell, P.G., Ramsey, C.B., Buck, C.E., Cheng, H., Edwards, R.L., Friedrich, M., Grootes, P.M., Guilderson, T.P., Haflidason, H., Hajdas, I., Hatte, C., Heaton, T.J., Hoffmann, D.L., Hogg, A.G., Hughen, K.A., Kaiser, K.F., Kromer, B., Manning, S.W., Niu, M., Reimer, R.W., Richards, D.A., Scott, E.M., Southon, J.R., Staff, R.A., Turney, C.S.M., van der Plicht, J., 2013. Intcal13 and Marine13 Radiocarbon Age Calibration Curves 050,000 Years Cal Bp. Radiocarbon 55, 1869-1887.

Roberts, N., Boyer, P., Merrick, J., 2007. The KOPAL on-site and off-site excavation and sampling programme, in: Hodder, I. (Ed.), Excavating Çatalhöyük: South, North and KOPAL Area reports from the 1995-1999 seasons. The MacDonald Institute for Archaeological Research and the British Institute at Ankara, Cambridge/Ankara, pp. 553-572.

Roberts, N., Eastwood, W.J., Kuzucuoğlu, C., Fiorentino, G., Caracuta, V., 2011. Climatic, vegetation and cultural change in the eastern Mediterranean during the mid-Holocene environmental transition. The Holocene 21, 147-162.

Roberts, N., Rosen, A., 2009. Diversity and Complexity in Early Farming Communities of Southwest Asia: New Insights into the Economic and Environmental Basis of Neolithic Catalhoyuk. Curr Anthropol 50, 393-402.

Robinson, E., Van Strydonck, M., Gelorini, V., Crombe, P., 2013. Radiocarbon chronology and the correlation of hunter-gatherer sociocultural change with abrupt palaeoclimate change: the Middle Mesolithic in the Rhine-Meuse-Scheldt area of northwest Europe. Journal of Archaeological Science 40, 755-763.

Robinson, S., Black, S., Sellwood, B., Valdes, P.J., 2006. A review of palaeoclimates and palaeoenvironments in the Levant and Eastern Mediterranean from 25,000 to 5000 years BP: setting the environmental background for the evolution of human civilisation. Quaternary Science Reviews 25, 1517-1541.

Rohling, E.J., Pälike, H., 2005. Centennial-scale climate cooling with a sudden cold event around 8,200 years ago. Nature 434, 975-979.

Rollefson, G.O., 1998. Expanded radiocarbon chronology from 'Ain Ghazal. Neo-Lithics 98-2, 8-10.

Rollefson, G.O., 2008. The Neolithic Period, in: Adams, R.B. (Ed.), Jordan: An Archaeological Reader. Equinox Publishing, London.

Roodenberg, J., van As, A., Alpaslan-Roodenberg, S., 2008. Barcin Hüyük in the Plain of Yenişehir (2005-2006). A preliminary note on the fieldwork, pottery and human remains of the prehistoric levels. Anatolica 34, 53-60.

Roodenberg, J.J., Schier, W., 2001. Radiocarbon determinations, in: Roodenberg, J.J., Thissen, L. (Eds.), The Ilıpınar Excavations II. Nederlands Instituut voor het Nabije Oosten, Leiden, pp. 257-278.

Rooijakkers, C.T., 2012. Spinning animal fibres at Late Neolithic Tell Sabi Abyad, Syria? Paléorient 38, 93-109.

Russell, A., 2010. Retracing the Steppes: A zooarchaeological analysis of changing subsistence patterns in the Late Neolithic at Tell Sabi Abyad, Northern Syria, c. 6900 to 5900 BC, Faculty of Archaeology. Leiden University, Leiden.

Russell, A., Buitenhuis, H., 2008. Tell Damishliyya faunal bone report. Anatolica 34, 315-338.

Russell, N., Martin, L., 2005. Çatalhöyük mammal remains, in: Hodder, I. (Ed.), Inhabiting Çatalhöyük: reports from the 1995-1999 seasons. McDonald Institute, Cambridge, pp. 33-98. 
Schmidt, A., Quigley, M., Fattahi, M., Azizi, G., Maghsoudi, M., Fazeli, H., 2011. Holocene settlement shifts and palaeoenvironments on the Central Iranian Plateau: Investigating linked systems. Holocene 21, 583-595.

Scott, E.M., Bryant, C., Carmi, I., Cook, G., Gulliksen, S., Harkness, D., Heinemeier, J., McGee, E., Naysmith, P., Possnert, G., van der Plicht, H., van Strydonck, M., 2004. Precision and accuracy in applied ${ }^{14} \mathrm{C}$ dating: some findings from the Fourth International Radiocarbon Intercomparison. Journal of Archaeological Science 31, 1209-1213.

Shennan, S., Downey, S.S., Timpson, A., Edinborough, K., Colledge, S., Kerig, T., Manning, K., Thomas, M.G., 2013. Regional population collapse followed initial agriculture booms in midHolocene Europe. Nat Commun 4.

Shennan, S., Edinborough, K., 2007. Prehistoric population history: from the late glacial to the late neolithic in central and northern Europe. Journal of Archaeological Science 34, 1339-1345.

Sillitoe, P., 1993. A ritual response to climatic perturbations in the Highlands of Papua New Guinea. Ethnology 32, 169-185.

Sperling, M., Schmiedl, G., Hemleben, C., Emeis, K.C., Erlenkeuser, H., Grootes, P.M., 2003. Black Sea impact on the formation of eastern Mediterranean sapropel S1? Evidence from the Marmara Sea. Palaeogeography Palaeoclimatology Palaeoecology 190, 9-21.

Spurk, M., Leuschner, H.H., Baillie, M.G.L., Briffa, K.R., Friedrich, M., 2002. Depositional frequency of German subfossil oaks: climatically and non-climatically induced fluctuations in the Holocene. Holocene 12, 707-715.

Staubwasser, M., Weiss, H., 2006. Holocene climate and cultural evolution in late prehistoric-early historic West Asia. Quaternary Research 66, 372-387.

Stevens, L.R., Wright, H.E., Ito, E., 2001. Proposed changes in seasonality of climate during the Lateglacial and Holocene at Lake Zeribar, Iran. Holocene 11, 747-755.

Taylor, R.E., 1987. Radiocarbon dating: An archaeological perspective. Academic Press, London.

Teller, J.T., Leverington, D.W., Mann, J.D., 2002. Freshwater outbursts to the oceans from glacial Lake Agassiz and their role in climate change during the last deglaciation. Quaternary Science Reviews 21, 879-887.

Thomas, E.R., Wolff, E.W., Mulvaney, R., Steffensen, J.P., Johnsen, S.J., Arrowsmith, C., White, J.W.C., Vaughn, B., Popp, T., 2007. The 8.2 ka event from Greenland ice cores. Quaternary Science Reviews 26, 70-81.

Timpson, A., Colledge, S., Crema, E., Edinborough, K., Kerig, T., Manning, K., Thomas, M.G., Shennan, S., 2014. Reconstructing regional population fluctuations in the European Neolithic using radiocarbon dates: a new case-study using an improved method. Journal of Archaeological Science.

Turner II, B.L., Sabloff, J.A., 2012. Classic Period collapse of the Central Maya Lowlands: Insights about human-environment relationships for sustainability. P Natl Acad Sci USA 109, 1390813914.

van der Plicht, J., Akkermans, P.M.M.G., Nieuwenhuyse, O., Kaneda, A., Russell, A., 2011. Tell Sabi Abyad, Syria: Radiocarbon chronology, cultural change, and the 8.2 ka event. Radiocarbon 53, 229-243.

van der Plicht, J., Bruins, H.J., 2001. Radiocarbon dating in near-Eastern contexts: Confusion and quality control. Radiocarbon $43,1155-1166$.

van der Plicht, J., Bruins, H.J., 2005. Quality control of Groningen ${ }^{14} \mathrm{C}$ results from Tel Rehov: Repeatability and intercomparison of Proportional Gas Counting and AMS, in: Levy, T.E., Higham, T. (Eds.), The Bible and Radiocarbon Dating - Archaeology, Text and Science. Equinox, London, pp. 256-270.

van Oldenborgh, G.J., 2015. KNMI Climate Explorer. KNMI, climexp.knmi.nl/.

Verheyden, S., Nader, F.H., Cheng, H.J., Edwards, L.R., Swennen, R., 2008. Paleoclimate reconstruction in the Levant region from the geochemistry of a Holocene stalagmite from the Jeita cave, Lebanon. Quaternary Research 70, 368-381.

Veski, S., Seppa, H., Ojala, A.E.K., 2004. Cold event at 8200 yr BP recorded in annually laminated lake sediments in eastern Europe. Geology 32, 681-684.

von Grafenstein, U., Erlenkeuser, H., Müller, J., Jouzel, J., Johnsen, S., 1998. The cold event 8200 years ago documented in oxygen isotope records of precipitation in Europe and Greenland. Climate Dynamics 14, 73-81.

Weeks, L., 2013. The Neolithisation of Fars, Iran, in: Matthews, R., Fazeli Nashli, H. (Eds.), The Neolithisation of Iran. Oxbow Books, Oxford, pp. 97-107.

Weeks, L., Alizadeh, K., Niakan, L., Alamdari, K., Zeidi, M., 2006. The Neolithic settlement of highland SW Iran: New evidence from the Mamasani District. Iran 44, 1-31. 
Weiss, H., Bradley, R.S., 2001. What drives societal collapse? (vol 291, pg 609, 2001). Science 291, 988-988.

Weiss, H., Courty, M.-A., Wetterstrom, W., Guichard, F., Senior, L., Meadow, R., Curnow, A., 1993. The Genesis and Collapse of Third Millennium North Mesopotamian Civilization. Science 261, 995-1004.

Weninger, B., Alram-Stern, E., Bauer, E., Clare, L., Danzeglocke, U., Joris, O., Claudia, K.E., Gary, R.F., Todorova, H., van Andel, T., 2006. Climate forcing due to the 8200 cal yr BP event observed at Early Neolithic sites in the eastern Mediterranean. Quaternary Research 66, 401420.

Weninger, B., Clare, L., 2011. Holocene rapid climate change in the Eastern Mediterranean. An emerging archaeological climate research program, in: Krauss, R. (Ed.), Beginnings - New Research in the Appearance of the Neolithic between Northwest Anatolia and the Carpathian Basin. Verlag Marie Leidorf, Rahden, pp. 11-22.

Weninger, B., Clare, L., Gerritsen, F., Horejs, B., Krauss, R., Lindstädter, J., Özbal, R., Rohling, E.J., 2014. Neolithisation of the Aegean and Southeast Europe during the 6600-6000 calBC period of rapid climate change. Documenta Praehistorica.

Weninger, B., Clare, L., Rohling, E.J., Bar-Yosef, O., Bohner, U., Budja, M., Bundschuh, M., Feurdean, A., Gebel, H.G., Joris, O., Linstadter, J., Mayewski, P., Muhlenbruch, T., Reingruber, A., Rollefson, G., Schyle, D., Thissen, L., Todorova, H., Zielhofer, C., 2009. The Impact of Rapid Climate Change on prehistoric societies during the Holocene in the Eastern Mediterranean. Doc Praehist 36, 7-59.

Weninger, B., Jöris, O., Danzeglocke, U., 2013. CalPal: Cologne Radiocarbon CALibration \& PALaeoclimate research package; Europe database. 2013 version.

Wick, L., Lemcke, G., Sturm, M., 2003. Evidence of Lateglacial and Holocene climatic change and human impact in eastern Anatolia: high-resolution pollen, charcoal, isotopic and geochemical records from the laminated sediments of Lake Van, Turkey. Holocene 13, 665-675.

Wicks, K., Mithen, S., 2014. The impact of the abrupt 8.2 ka cold event on the Mesolithic population of western Scotland: a Bayesian chronological analysis using 'activity events' as a population proxy. Journal of Archaeological Science 45, 240-269.

Wiersma, A.P., Renssen, H., 2006. Model-data comparison for the $8.2 \mathrm{ka} \mathrm{BP}$ event: confirmation of a forcing mechanism by catastrophic drainage of Laurentide Lakes. Quaternary Science Reviews 25, 63-88.

Williams, A.N., 2012. The use of summed radiocarbon probability distributions in archaeology: a review of methods. Journal of Archaeological Science 39, 578-589. 